\title{
OFFSHORE CASUALTIES IN CANADIAN WATERS
}

\author{
TOSH HAYASH *
}

This paper discusses the actions which can arise out of an offshore accident in Canadian waters. The relevant Federal and Newfoundland workers' compensation legislation is analyzed along with possible statutory bars to civil actions. Relevant topics in tort and contract are reviewed and the author discusses means by which an employer can limit his liability.

The recent "Ocean Ranger" drill rig disaster makes one recall that in 1980 a Norwegian accommodation rig (a converted drill rig), the "Kielland", capsized and one hundred and twenty-three lives were lost. Recently it was reported that claims "by survivors and relations of workers killed ... against Phillips Petroleum and its Norwegian subsidiary amount to more than two billion dollars" and that Phillips had "already paid out about twelve million dollars under Norwegian compensation laws."

In this paper, certain matters relevant to the litigation expected to arise from such offshore casualties will be discussed. The order of discussion will be as follows:

I An "Ocean Ranger" type disaster scenario will be described to set a context of assumed "real" events for the rather abstract discussions of law that follow.

II Worker's compensation legislation will be discussed. Such legislation is important in that it limits the rights of action of workers against their own employers and against other employers and in that it purports to give the provincial Compensation Board "exclusive jurisdiction" over all issues arising out of such accidents, including whether a worker's or dependant's right of action is barred under the legislation. The emphasis will be on The Workers' Compensation Act ${ }^{2}$ of Newfoundland.

III The (federal) Merchant Seamen Compensation $\mathrm{Act}^{3}$ will be discussed. In the offshore scenario, it may apply instead of a provincial compensation scheme.

IV The problem of deciding which compensation scheme, federal or provincial, applies to the offshore rig worker will be discussed. This problem is bound up with the questions of legislative competence and jurisdiction of coastal states in relation to the offshore in the

* Metcalf \& Holm, Halifax, Nova Scotia. The author thanks Sheila F. McAllister, Professor Norman Letalik of Dalhousie Ocean Studies Programme, Frank Metcalf, Carl Holm, Judy Hayashi and Pat Nicoll for reading previous drafts and making helpful suggestions for revision. The author also thanks Ted McDorman for providing useful information on the implementation of the U.N. Convention on the Law of the Sea. Last, but not least, the author thanks Mrs. Diana Bywater for patiently typing the various versions or mutations of this paper.

1. Lloyd's Maritime Law Newletter, March 18, 1982. The Globe and Mail, December 14, 1982 , reports that as of July, 1982, thirty-one lawsuits had been filed in U.S. Federal Courts by Canadian families of workers who died in the Ocean Ranger disaster of February 14, 1982. These claims apparently total 226 million dollars.

2. R.S.N. 1970, c. 403.

3. R.S.C. 1970, c. M-11. 


\section{context of international law.}

V There will be a discussion of selected matters relevant to the types of tort actions that can be expected to arise from an offshore casualty.

VI Contractual and non-contractual devices that can be used by an employer to attempt to limit his liabilities in the event of an offshore casualty will be discussed.

VII Conclusion and summary.

\section{SCENARIO}

Assume the following hypothetical facts.

An oil rig, semi-submersible, sinks with all hands lost within Canada's 200 mile economic control zone, about 175 miles off St. John's, Newfoundland. The rig had been drilling in the Hibernia field and went down in 200 feet of water during a storm with $\mathbf{5 0}$ foot seas. It was Canada's worst marine disaster since World War II.

The rig was built by a Japanese company and designed to operate in 1,500 feet of water and drill to depths of 25,000 feet. It was self-propelled. It was moored in place, for drilling purposes, by twelve 45,000 pound anchors. Like the Titanic, it was touted to be virtually unsinkable. Its replacement cost when it went down was placed conservatively as approximately 200 million dollars (U.S.).

On board there were four 33 foot fibreglass lifeboats with covers and twelve inflatable liferafts. The boats could hold 50 to 58 people, the rafts 12 each. The rig could accommodate 100 .

Eighty-four persons were on board when it went down. Some of the lifeboats were later found upside down, with cracked hulls and dead bodies inside. There were only a few survival suits on board when the rig went down. Only a few of the bodies found had survival suits on.

At this point in time no competent tribunal has discovered what caused the casualty. Rumours abound that it was caused by human operating error, or by a structural defect, by a defect of design, by inadequacies in the ship's safety equipment, by inadequate training of the rig's personnel in safety procedures, or by evident malfunctions in the rig's control systems which had surfaced the previous week and which should have alerted those in charge of the rig to call it in for inspection and overhaul.

The Federal Minister of Energy Mines and Resources said his department had inspected the rig two weeks before the casualty and everything seemed in good order then. Six months before, the American Bureau of Shipping had made an inspection and had passed the rig.

It is also alleged that while the rig was in place and not navigating, the drilling crew was in charge of the overall operations of the rig and that the marine crew, including master and mate, spent much of their time, when not checking out their navigational equipment, in their bunks sleeping, or in recreational facilities, reading, or playing cards, and that when the rig started to go down the marine crew did not assume charge of its operation until it was too late to avert the disaster.

Some of the companies with employees on the rig had been paying into the Newfoundland Workers' Compensation scheme. The Newfoundland Worker's Compensation Board stated to the news media that it had jurisdiction over the matter and that by virtue of provisions in the Worker's 
Compensation Act ${ }^{4}$, survivors and dependants would not be able to sue the employers of the deceased or any other employer on the rig. However, legal opinion in certain other quarters was to the effect that workers' compensation legislation had no application to the situation at all.

The rig was registered as a United States flag vessel owned by an American company, Ocean Exploration Ltd. (Ocean). It was leased by National Oil of Canada (National).

Personnel on board the vessel when the rig went down included the crews of Ocean Exploration and National Oil. There were also crews of several other companies, subcontractors of the owner, Ocean, and of the lessee, National. Most of the personnel were employed by Ocean who provided a fairly large drilling crew, and a smaller marine crew. National's crew provided the geological and scientific expertise for the drilling activities, subcontracting certain areas of its responsibility to specialized companies such as Mud Analysts of Canada who did the soils analysis or mud logging.

The vast majority of employees were Canadian residents, most of these from Newfoundland. Others were from Nova Scotia, Ontario and Alberta. A few were from the United States and the United Kingdom.

A flood tide of litigation by survivors and dependants is feared in corporate and insurance circles. In particular, what is feared is that numerous actions will be started in the United States, where it almost seems million dollar awards for wrongful injury or death have become everyday occurrences.

\section{WORKERS' COMPENSATION LEGISLATION}

At common law, prior to the enactment of workers' compensation legislation, an injured worker was precluded from succeeding in a claim for damages where he was injured through the negligence of another workman. The employer could rely on the defences of "common employment" (which relieved the employer from vicarious liability for accidents caused by the negligence of a worker's fellow servants)", "voluntary assumption of risk", ${ }^{6}$ and "contributory negligence" (which provided a complete bar to the action until the introduction of apportionment or contributory negligence legislation). ${ }^{7}$

In the twentieth century, the legislatures began to create new legislation aimed at reducing the harshness of the common law by providing workers and their dependants with adequate remedies for compensation in the event of injury or death. The creation of workers' compensation legislation was part of this reform movement. Today the overwhelming proportion of claims arising out of industrial accidents is met by claims under workers' compensation legislation, rather than by common law litigation. ${ }^{8}$

In Canada, all ten provinces have workers' compensation legislation. While basically similar, the statutes have some significant differences

4. Supran. 2.

5. J. Fleming, The Law of Torts (5th ed., 1977) 489. See also Canadian Pacific Railway Co. v. Cheeseman (1918) 58 S.C.R. 439 at 450, per Mignault J.

6. Fleming, id. at $486-489$.

7. Id at 489 .

8. Id at $493-497$. 
with respect to certain matters, such as the extent of the compensation board's subrogation rights. Federally, there is no general workers' compensation legislation because it has been held that workers' compensation legislation is legislation in respect of "civil rights" which is a head of power within the exclusive competence of the provinces $s^{9}$ under the B.N.A. Act (which is now incorporated as part of the Constitution Acts, 1867 - 1981).

Aside from coverage given by that curious federal anomaly called the Merchant Seamen Compensation Act, ${ }^{10}$ in the "private sector"11 workers' compensation coverage is provided by one or more of the provincial workers' compensation schemes. Provincial compensation is provided even in respect of workers who, for employment law and collective bargaining purposes, come under federal legislation. ${ }^{12}$

Even if workers on offshore rigs are found to come under federal jurisdiction for purposes of employment and labour law, ${ }^{13}$ prima facie, for compensation purposes, they nevertheless are covered by one of the provincial compensation schemes. Failing that, a rig worker may be covered by

9. I.M. Christie, Employment Law in Canada (1980) 33-34, 207-209.

10. Supran. 3.

11. In the federal public sector, the Government Employees Compensation Act, R.S.C. 1970 , c. G-8, applies to federal government employees, including employees of federal crown companies, in certain situations. This legislation is apparently not in conflict with provincial compensation legislation. It provides a federal fund called the "Consolidated Revenue Fund" which can be tapped for two main purposes: to provide contributions to provincial or other compensation funds on behalf of federal employees claiming compensation from such funds, as deemed necessary by the federal Minister of Labour; and to provide direct compensation to federal employees or dependants thereof where such employees were engaged outside of Canada and who are not entitled to compensation under any other law. In this latter category we would expect such people, for example, as federal employees working in embassies, consulates, and trade commissions in foreign countries.

12. Workers' compensation, as noted previously, is a matter of civil rights and thus within provincial jurisdiction. By contrast, employment and labour law is both provincial and federal under a divided jurisdiction: i.e, if the employment or labour is "integral to or essential for" a work or undertaking falling within one of the heads of federal lawmaking power in s. 91 of the B.N.A. Act, the jurisdiction will be federal; if not, it will be provincial. See Christie, supra n. 9 at 44 et seq.

13. With respect to offshore activities, the Federal Court of Appeal recently held the federal government has exclusive jurisdiction over labour relations aboard vessels supplying drill rigs off our East Coast. The three man Court unanimously decided supply vessels were involved in "shipping", which is under federal jurisdiction. The work involved on offshore vessels included towing rigs, positioning anchors, supplying materials to the rigs, and providing iceberg patrol services. The president of the Seafarers' International Union said the decision would open the door to vigorous organizing campaigns not only among workers on offshore supply vessels, but also among workers on offshore rigs. In arriving at their decision, the Court ignored the current dispute between Canada and Newfoundland as to who owns the offshore resources. See The Globe and Mail, March 10, 1982, p. 3. See also Seafarers' International Union of Canada-CFL-AFL-C10 v. Crosbie Offshore Services Ltd, unreported, F.C. No. A-2-81, per the decision of Thurlow C.J.A. The Supreme Court of Canada, on May 10, 1982, refused to hear an appeal on the issue. See The Globe and Mail, May 11, 1982. 
the Merchant Seamen Compensation Act. ${ }^{14}$ It is possible, however, that a rig worker is covered by neither compensation scheme, depending on the facts of his particular case.

Assume, however, that either the Newfoundland Workers' Compensation Act or the Merchant Seamen Compensation Act applies to the scenario that was presented earlier. This paper will now explore the effect of specific provisions in both Acts relevant to (1) the benefits that can be claimed, and (2) the limitations they put on litigation against employers.

\section{A. Newfoundland Workers' Compensation Scheme}

\section{Part I of The Act}

Where death or injury to a workman arises "out of and in the course of employment" in an industry falling within Part I of The Workers' Compensation Act ${ }^{15}$, compensation is to be paid in accordance with the Act to the workman or his dependants. ${ }^{16}$

The levels of compensation are modest, ${ }^{17}$ but that should be considered in the context of the expense and difficulty involved in litigating personal injury and wrongful death claims through the courts. Compensation is paid out of an accident fund.$^{18}$ Every employer to which Part I applies pays into the accident fund as assessed and levied by the board. ${ }^{19}$ Where a nonfatal accident occurs on board a vessel, compensation is not payable for the period during which, if any, the owner of the vessel is subject to Part IV of the Canada Shipping Act; and where there is a fatal accident and the owner of the vessel is liable to pay the expenses of burial, such expenses are not payable out of the accident fund established by the Newfoundland Act. $^{20}$

14. Supra n. 3. In its application, the federal Act cannot conflict with the provincial compensation Acts for that would make it ultra vires. By explicit limitations on who can obtain compensation, this federal Act would appear to have avoided such conflict. The legislation contemplates seamen who do not qualify for compensation under provincial schemes because, for example, they are not residents of a province or because the usual place of work is not within a province but on the high seas. Ostensibly, this would be legislation in relation to general maritime law, and under federal jurisdiction as per "navigation and shipping". See further discussion of this legislation in fra.

15. Supra n. 2, s. 3. Also see The Workers' Compensation Regulations, 1974, Nfld. Reg. $277 / 78$, as am..

16. Id., 8. 6(1): "Where, in an industry within the scope of this Part, personal injury by accident arising out of and in the course of employment is caused to a workman, compensation shall be paid in accordance with this Act to the workman or his dependants, as the case may be, but where the injury is attributable solely to the serious and wilful misconduct of the workman compensation is not payable unless the injury results in death or serious and permanent disablement." (In Re Kinney and Workmen's Compensation Board (1972) 27 D.L.R.(3d) 703 (N.B.S.C.A.D.) the question as to what arises out of and in the course of employment was given a broad or liberal interpretation.)

17. Id. See ss. 45-56 and also The Workers' Compensation Orders, 1981, Nfld. Reg. 197/81.

18. Id, ss. 63 and 64 .

19. Id, s. 65 et seq.

20. Id, s. 8. (Part IV of the Canada Shipping Act, R.S.C. 1970, c. S-9, deals inter alia with payment of expenses of medical attendance, maintenance, burial and repatriation of seamen. Under s. 283(1) of that Act the owner of a Canadian ship is to defray such expenses where the injury or illness was not due to the seaman's "own wilful act or default or ... misbehaviour," and is not to deduct these from seaman's wages. Under 8. 283.1, the owner of a non-Canadian ship is liable for the cost of all medical, surgical and hospital care provided in Canada to a person employed on such ship.) 
In any event, only a claim for compensation under the Act may be made and no action can be taken against the immediate employer of the injured or deceased workman. ${ }^{21}$ However, that limitation does not apply if the workman and the work he was engaged in at the time of the accident were not within the operation of Part I of the Act. ${ }^{22}$

Where the accident occurs in such circumstances that the injury or death is caused by another employer or a workman of another employer, neither the victim, his dependants nor his own employer has any right of action against any other employer or workman in an industry within the scope of Part I..$^{23}$ However, that limitation does not apply if the accident occurred "otherwise than in the conduct of operations usual in or incidental to the industry carried on by the employer."24 That limitation also does not apply to any rights of action or indemnity one employer may have against another employer "arising out of a contract or agreement made between the employers." 25

Assuming that the limitations set out above do not apply, and that the worker or his dependant has a right of action against somebody other than the immediate employer, "if they are entitled to compensation, [they] may claim compensation or may bring an action." ${ }^{26}$ This calls for an election. Where worker or dependant elects compensation, the Board is dominus litus and it alone can decide whether to initiate an action and it alone has complete control over all aspects of the proceeding. The worker or dependant in such case is not also entitled to bring his own action, at least on a

21. Supra n. 2, s. 13(1), says the right to compensation is "in lieu of all rights and rights of action" against the workman's employer. (See Paré v. Rail \& Water Terminal (Quebec) Inc. [1978] 1 F.C. 23: action against employer dismissed as both Workmen's Compensation Act, R.S.Q. 1964, c. 159, as am., and Merchant Seamen Compensation Act (supra n. 3) prohibit such actions. The court, however, does not decide which act applies. This case is discussed again infra.) In the Nova Scotia Workers' Compensation Act, R.S.N.S. 1967 , c. 343, as am., s. 16 says the same thing with a slight difference in wording.

22. Id. s. 13(2). (The reader should keep in mind that the question as to whether the work is within the scope of Part 1 will probably be answered very liberally. In Commission des Accidents du Travail de Quebec v. Buchanan (1976) 78 C.L.L.C. 14, 155 (Que.S.C.), workers in a "law office" were held to be in an "industry" covered by the Workmen's Compensation Act.) In the Nova Scotia Act, see s. 16, id.

23. Id., s. 12(1). See for example Gibb v. Munro (1978) 87 D.L.R.(3d) 225 (B.C.S.C.), and MacKinnon v. Fitzgerald \& Snow Ltd. (1973) 44 D.L.R.(3d) 535 (P.E.I.S.C. in banco); and for Nova Scotia, see n. 21, supra, s. 15.

24. Id., s. 12(1). The quoted qualification will probably be given a narrow or restricted interpretation which will make it difficult to come within the exception. See for example Re Kinney supra $n$. 16. The fact that what arises out of and in the course of employment will be given a broad or liberal interpretation, conversely means that it will be difficult to satisfy the condition "otherwise than in the conduct of operations usual and/or incidental to the industry carried on by the employer." But also see Levy v. J. P. Porter \& Sons Ltd. (1946) 19 M.P.R. 201 (N.S.S.C. in banco); removing anchors from an abandoned dredge not dredging or work incidental thereto.

The Nova Scotia Act does not have this qualification, although it does exclude the operation of the limitation for motor vehicle accidents, supra n. 21, s. 15A.

25. Id, s. 12(3). Indemnity agreements between employers on oil rigs will be discussed infra. The Nova Scotia Act does not appear to have this provision.

26. Id., s. 11(1), and for the Nova Scotia Act, s. 14(1) which, however, requires written notice of election within six months of date of accident. 
strict reading of that provision. ${ }^{27}$ If they elect to bring an action, and recover less than they would have been entitled to under the Act, they can still make a claim for the shortfall.$^{28}$ However, if they claim compensation, the Workers' Compensation Board "shall be subrogated to the rights of the workman or his dependants and may maintain an action ... for the whole or an outstanding part of the claim of the workman or his dependants" against the person against whom the action lies. ${ }^{29}$ This subrogation right is total in respect of all rights of the worker or dependant and does not depend on how much compensation is paid. ${ }^{30}$

In Quebec's legislation, the Board has only a partial subrogation right equivalent to the compensation paid out and expenses incurred by it. ${ }^{31}$ Thus in Quebec, if the Court awards more than the compensation paid and the expenses incurred by the Board, the worker or dependant is entitled to the excess. By contrast, the Newfoundland statute provides only that where the amount recovered exceeds the compensation paid out, the excess less costs and administration charges "at the discretion of the Board" may be paid to the workman or dependant, but such workman or dependant is not entitled to that sum "as a matter of right". ${ }^{32}$

The Compensation Board has exclusive jurisdiction to examine, hear and determine all matters and questions arising under Part I. But the Board's decision may be appealed to the Trial Division of the Supreme Court of Newfoundland, where the issue concerns the Board's jurisdiction,

27. See MacIntosh v. Gzowski (1979) 105 D.L.R.(3d) 721 (Ont.C.A.), which considered the effect of s. 8(1) of the Ontario Workmen's Compensation Act, R.S.O. 1970, c. 505, which is also identical to s. 11(1) of the Newfoundland Act. But see Knickle v. Tanner (1974) 48 D.L.R.(3d) 458 (N.S.S.C.) - injured worker obtained compensation and then sued third party tortfeasor, Workmen's Compensation Board joined as third party; although Board subrogated to all damages awarded, plaintiff worker was entitled to share in the costs since he carried the action. Section 14(1) of the Nova Scotia Act is almost identical to s. 11(1) of the Newfoundland Act. See n. 30, infra, for further discussion of this case.

28. Supra n. 2, s. 11(2), and in the Nova Scotia Act, s. 14(2).

29. Id., s. 11(3), same provision in the Nova Scotia Act, s. 14(3).

30. See Knickle v. Tanner (1974) 48 D.L.R.(3d) 458 (N.S.S.C.), affd. (1974) 57 D.L.R.(3d) 367 (N.S.S.C.A.D.). Defendant, who was not a worker, negligently drove his car into materials which then hit plaintiff. Defendant said since plaintiff received compensation, he had no status and any rights of action vested in the Compensation Board, which was joined as a third party. Held, that Board was entitled to the award. Courts considered effect of s. 14(3) of the Nova Scotia Workmen's Compensation Act, R.S.N.S. 1967, c. 343, which is virtually identical to s. 11(3) of the Newfoundland Act. Court of Appeal held that the subrogation rights assumed by Board when workman elected compensation extended beyond pecuniary damages payable under the Act, to amounts assessed for pain and suffering and permanent partial disability. Court distinguished subrogation rights under Nova Scotia Act from corresponding provision in the Quebec Act which only gave a partial subrogation right to the Quebec Board. Reference made to Mingarelli v. Montreal Tramways Co. [1959] S.C.R. 43 at 46.

31. See discussion of Knickle, id.

32. Supra n. 2, s. 11(6). The Nova Scotia Act does not have this provision. The "discretion" the Newfoundland Board has might be invoked where to withhold the excess from worker or dependant would be considered highly unpopular or unhumanitarian. 
a question of law, or a question of mixed law and fact. ${ }^{33}$ There are serious questions as to whether such a Board can exert its "exclusive" jurisdiction over accidents occurring on the offshore, which is beyond provincial boundaries as we know them. This issue is returned to at several points in the discussion that follows.

\section{Part II of the Act}

Part II of the Act applies to industries to which Part I does not apply and to workmen in those industries, including casual workers employed "otherwise than for the purpose of their employer's trade or business" and to workers and industries that are by regulation excluded from the operation of Part I..$^{34}$ Part II, however, does not apply to domestic or menial servants or their employers. ${ }^{35}$

Where Part II applies, the immediate employer becomes open to certain occupier's strict liability actions and negligence actions. That is, he becomes open to legal actions by an employee or dependant for injury or death resulting from "any defect in the condition or arrangement of the ways, works, machinery, plant, buildings or premises connected with or intended for or used in the business of his employer or by reason of the negligence of his employer or any person in the service of his employer acting within the scope of his employment". ${ }^{36}$

The damages recoverable from the employer in those circumstances are "the damages which the workman sustained by or in consequence of the injury caused to him." 37 But if the action is brought under The Fatal Accidents Act, damages recoverable are limited to the damages stated in that Act; this would basically limit damages to loss of economic support and services. ${ }^{38}$

The liabilities in respect of loss and injury caused by defective ways, works, or machinery, extend to the person for whom the work was done if he owns or supplies those defective structures, and such supplier is to be treated as the employer of the workman for purposes of the action. However, the contractor or subcontractor that actually employed the workman remains liable also "but not so that double damages are recoverable for

33. Id., ss. 37(1) and 38(1). See Re Lanteigne and Workmen's Compensation Board(1973) 41 D.L.R.(3d) 764 (N.B.S.C.A.D.) and Mack Trucks Manufacturing Co. of Canada Ltd. v. Forget (1973) 41 D.L.R.(3d) 421 (S.C.C.). In the latter case, after worker got compensation, Board brought an action against the defendant in worker's name. Worker had been driving motor vehicle in course of his employment and had collision with second vehicle owned by the defendant company which was on loan to another company. Defendant claimed he was a protected employer under the Act and could not be sued. At trial, action was dismissed. Ontario Court of Appeal said the action was to be restored and proceedings stayed to permit either party to apply to the Board for determination as to whether the action was barred. Supreme Court of Canada agreed Board had exclusive jurisdiction to determine such matters and dismissed defendant's appeal. But see notes 61 and 62 infra.

34. Supra n. 2, ss. 99 and 5. Part II of the Nova Scotia act, as contained in ss. 160 to 164. Section 160 merely says Part II applies to industries to which Part I does not apply and to the workmen employed in such industries.

35. Id., s. 103.

36. Id, s. $100(1)$. See Levy v. J. P. Porter \& Sons Ltd. supra n. 24. In the Nova Scotia Act, see s. $161(1)$.

37. Id, s. $100(2)$, and for Nova Scotia, $i d$.

38. Id., s. 100(3), and for Nova Scotia, id.

39. Id., s. 100(4), and in the Nova Scotia Act, s. 161(2). 
the same injury." ${ }^{39}$ Nothing in the previous provision, however, affects any rights or liabilities "as between" contractors and subcontractors and the person for whom the work is done. ${ }^{40}$

Section 101 states that a workman to whom Part II applies is deemed not to have undertaken the risk of negligence by a fellow workman and that his own contributory negligence is not a bar to recovery "for an injury sustained by or causing the death of a workman while in the service of the employer for which the employer would otherwise have been liable." Section 101 does not explicitly abrogate those common law defences for actions against other employers and their workmen. However, the combined effect of section 101 and section 100(4) is to abrogate those defences for actions against another employer for whom the work is being done and who owns or supplies the defective structures.

Even if contributory negligence is not a bar to recovery, as provided for in section 101, it is to be taken into account in assessing damages. ${ }^{41}$

It should be noted that where Part II applies, and the issue is not covered explicitly or implicitly by anything stated in Part II, the litigant must fall back on the common law or other legislation (or both) for the answer.

\section{THE MERCHANT SEAMEN COMPENSATION SCHEME}

The Merchant Seamen Compensation Act ${ }^{42}$ provides a right to compensation to a "seaman" or his dependants for injuries or wrongful death occurring while working on a Canadian registered ship or a ship chartered by demise to a Canadian resident or person having his principal place of business in Canada. ${ }^{43}$ The following definitions given in $\mathrm{s}$. 2 should be noted:

"Dependants" means such of the members of the family of a seaman as were wholly or partly dependent upon his earnings at the time of his death, or who but for the incapacity due to the accident would have been so dependent;

"employer" includes every person having any seaman in his service under a contract of hiring or apprenticeship, written or oral, express or implied;

"seaman" means every person, except pilots, apprentice pilots and fishermen, employed or engaged on

(a) a ship registered in Canada, or

(b) a ship chartered by demise to a person resident in Canada or having his principal place of business in Canada,

when such ship is engaged in trading on a foreign voyage or on a home-trade voyage as these voyages are defined in the Canada Shipping Act; and, if so ordered by the Governor in Council, includes a seaman engaged in Canada and employed on a ship that is registered outside Canada and operated by a person resident in Canada or having his principal place of business in Canada when such ship is so engaged;

"ship" includes any description of vessel, boat or craft used or capable of being used solely or partly for marine navigation without regard to method or lack of propulsion.

The Act contains exceptions to the basic rule given above.

First, no compensation is payable if the seaman or dependant is entitled to compensation under any other provincial or federal scheme of compensation. ${ }^{4}$

40. Id. s. 100(5), and in the Nova Scotia Act, s. 161(3).

41. Id., s. 102. See Levy v. J. P. Porter, supra n. 24. In the Nova Scotia Act, see ss. 162 and 163.

42. R.S.C. 1970 , c. M-11.

43. Id, combined effect of ss. 2 and 7. See Paré v. Rail \& Water Terminal (Quebec), infra n. 21: held parents of deceased ship's engineer were not dependants.

44. Id., s. 4. 
Second, if the accident occurs in a foreign country and they are entitled to claim compensation under the laws of that foreign country, an election must be made as to whether the claim will be made under this Act or under foreign law. If no election is made, it is presumed they elected not to claim under this Act. ${ }^{45}$

Once an injury or death occurs, the employer of the seaman is to pay compensation as provided for in the Act, except where the injury does not disable the seaman for at least three working days, or when it was solely attributable to the "serious and wilful misconduct of the seaman unless the injury results in death or serious disablement." ${ }^{46}$ Every employer, as defined above, "shall cover by insurance or other means satisfactory to the Board, the risks of compensation arising under this Act." ${ }^{47}$

All claims for compensation are to be heard and determined by the Board, and "no action lies for the recovery of compensation under this Act." 4 ' That is, once the Board has decided, its conclusion is final. The Board is given exclusive jurisdiction over all matters and questions arising under the Act, with no right of appeal or review of the process to a higher body allowed. It is questionable, of course, whether such a privative clause could withstand any and all applications for certiorari. ${ }^{49}$

The Act explicitly prohibits direct action by the seaman or dependant against his immediate employer.$^{50}$ Whether it also prohibits direct action against any "other" employer subject to the Act is problematical. Section 23(5) says:

No seaman entitled to compensation under this Act or the dependants of such seaman have a right of action against an employer who is subject to this Act.

There is an apparent ambiguity in section 23(5) when it is taken in the context of the Act as a whole. Section 23(1) appears to allow an election between bringing an action against such other employer and claiming compensation. Further, section 7 refers to the "employer" as the employer of the seaman that is injured or killed; similarly section 25 and similarly, by implication, section 29 .

Such contextual analysis leads the writer to favour the opinion that the Act was not intended to prohibit actions against "other" employers. To the same point, section 23(5) lacks the explicit detail of section 12(1) of the Newfoundland Workers' Compensation Act ${ }^{51}$ which clearly does prohibit actions against "other" employers.

Where a right of action is available, but compensation is also available under this Act, an election must be made whether to claim compensation or bring such action. ${ }^{52}$ If an election is made to claim compensation under the Act, and compensation is paid by the employer, the employer becomes "subrogated to the rights of the seaman or his dependants and may

45. Id., 8. 5(1).

46. Id., s. 7.

47. Id., s. 29(1). The modest scale of compensation and its mode of application is set out in ss. 30 to 43.

48. Id., s. 11.

49. Id, s. 14. See Evans et al, Administrative Law Cases, Text and Materials, chapter 12.

50. Id., s. 12.

51. Supra n. 2; also see the Nova Scotia Act, s. 15.

52. Id., s. 23(1). 
maintain an action . . against the person against whom the action lies."

\section{WHICH COMPENSATION SCHEME APPLIES?}

There is no simple answer to this question.

Prima facie, the Newfoundland scheme applies only to Newfoundland residents. ${ }^{54}$ But the Newfoundland Act does give coverage to a non-resident worker if the place he comes from has reciprocal coverage for Newfoundland residents. ${ }^{55}$

A problem may arise from the fact that the casualty occurred outside of the province. The Newfoundland Act covers accidents occurring outside the province only under certain conditions: that is, if the "usual place of employment" of the worker is "in the province" and "the accident happens while the worker is employed out of the province for some purpose connected with his employment in the province ... unless the worker or his dependants are entitled to compensation under the law of the place where the accident happens." 56 Whether these conditions are satisfied in respect of a specific rig worker can be answered only by a close look at the nature of his employment contract and the specific connections of that employment with his employment within the province, if any.

There is little in the way of definitive case law to help one develop further the meaning of section 10(1) beyond what can be gleaned from a

53. Id, s. 23(3).

54. Supra n. 2, s. 9(4); for the Nova Scotia Act, see s. 12(2).

55. Id, s. $9(1)$, and in the Nova Scotia Act, s. 11. Under both acts, this non-resident coverage is discretionary only.

56. Id., s. 10(1), and in the Nova Scotia Act, s. 13(1). 


\section{plain reading of the words used. ${ }^{57}$}

Even more problematical perhaps is the fundamental question as to whether the operation of an oil rig constitutes an "industry" to which Part

57. In Workmen's Compensation Board v. Canadian Pacific Railway Co. (1919) 48 D.L.R. 218 (P.C.), the steamship "Princess Sophia" went down with all hands in Alaskan waters on a return journey from Skagway to Vancouver. Employer, incorporated by Dominion statute, owned and operated steam vessels sailing between B.C. ports and ports in the U.S.. Whether employer or employees were domiciled or resident in B.C. were never issues in the case - see decision of British Columbia Court of Appeal in 47 D.L.R. 487, per McPhillips J. A. at 492. When the B.C. Compensation Board decided to pay compensation to dependants of certain crew members, employer took Board to Court and obtained order restraining it from paying compensation. I can only guess that at this point in time, the employer was directly responsible for any compensation paid out and that the compensation scheme was not run like a mutual insurance fund as it is today. On appeal by the Board, the B.C.C.A. dismissed appeal in a split decision, majority holding s. 8(1)(b) of the act, S.B.C. 1916, c. 77, to be ultra vires.

Section 8(1)(b) provided where an accident happened while workman was employed elsewhere than in the province which would give a right to compensation if it happened in the province, he or his dependants were so entitled if the accident happened on a steamship, ship or vessel, or on a railway, and the workman was a resident of the province, and the nature of the employment was such that the work or service to be performed by the workman was to take place both within and without the province.

On further appeal to the Privy Council, the Board's jurisdiction to compensate the defendants was restored. Section $8(1)(b)$ was found to be intra vires. Per Viscount Haldane at 221.222:

The right conferred arises under 8.8 , and is the result of a statutory condition of the contract of employment made with a workman resident in the Province, for his personal benefit and for that of members of his family dependent on him. Where the services which he is engaged to perform are of such a nature that they have to be rendered both within and without the Province, he is given a right which enures for the benefit of himself and the members of his family dependent on him, not the less that the latter may happen to be non-resident aliens. This right arises, not out of tort, but out of the workman's statutory contract, and their Lordships think that it is a legitimate provincial object to secure that every workman resident within the Province who so contracts should possess it as a benefit conferred on himself as a subject of the Province. When he enters into this contract, it also appears to them to be within the power of the Province to enact that, if the employer does not fully contribute to the accident fund out of which the payment is normally to be made, the employer should make good to that fund the amount required for giving effect to the title to compensation which the workman acquired for himself and his dependents. The scheme of the Act is not one for interfering with rights outside the Province. It is in substance a scheme for securing a civil right within the Province....

Despite the generality of Viscount Haldane's statements, it is not clear how applicable they are to our scenario. The Newfoundland Act does not have any provision resem. bling said s. 8(1)(b). By the same token, the courts in that case never considered the applicability of a provision resembling s. 10(1) of the present Newfoundland Act. It was also obvious in that case that the work or employment had a real connection with mainland B.C. in that the ship made regular runs into and out of B.C. In our scenario that obvious connection with Newfoundland is missing. If the B.C. case can be restricted to its facts and to the question of the applicability of a legislated provision that does not exist in the Newfoundland legislation, its applicability is fairly limited indeed.

In Bonavista Cold Storage Co. v. Walters (1959) 43 M.P.R. 344 (Ex.Ct.), a fishing trawler was lost with all hands on the high seas. Employer admitted its liability to pay compensation. The issue addressed in that case, although not relevant to the issue under consideration, was an interesting one: whether employer could apply to limit his liability under the Canada Shipping Act in relation to his ability to pay compensation under the Workmen's Compensation Act. It was held by Dunfield D. J. A. that since such compensation was not "damages" it was not of the class of claims appropriate for limitation of liability applications. This result should have equal application to claims made under the Merchant Seamen Compensation Act. Another ship lost on "high seas" case is that of Pare, which is discussed infra.n. 21. This also sheds little light on our problem. 
I of the Act applies at all. Offshore oil drilling and exploration and the operation of oil rigs are not explicitly mentioned in the Act or regulations. It does not necessarily follow that the answer can be found by looking at the combined effect of fairly general provisions such as the following: ${ }^{58}$

1. section 2(n), which says that employment "means and refers to the whole or any part of any establishment, undertaking, work, operation, trade or business within the scope of this Act, and in the case of any industry not as a whole within the scope of this Act includes any department or part of such industry as would, if carried on separately, be within the scope of this Act";

2. section 2(q), which defines industry as including "the whole or any part of any industry, operation, undertaking, establishment, work, trade or business and, in the case of any industry, operation, undertaking, establishment, work, trade or business not as a whole within this Act, means any department or part of the industry, operation, undertaking, establishment, work, trade or business which would, if carried on by itself, be within this Act"; and

3. the fact that Part I of the Act applies explicitly to "diamonddrilling" by section 3(b), to "the operation of .. . ships" by section 3(e), to "navigation, stevedoring" by section $3(\mathrm{f})$ and to "any of the industries, operations, or occupations incidental to or connected with any of the industries, occupations, or operations enumerated" specifically, by section $3(\mathrm{~h})$.

Even if we assume oil rig activities are an industry contemplated under Part I of the Newfoundland Act, before an employer can rely on that statute to shield him from actions by injured workers or dependants, two other legal principles have to be considered. First, if the worker or dependant has "civil rights" outside a province, a province cannot legislate in derogation of those civil rights outside the province. ${ }^{59}$ Second, a worker's rights of action, which might be prejudiced if he in fact actually received

58. On the other hand, as already mentioned, the Board will probably take a fairly liberal approach to this issue: see $\mathrm{n}$. 22, supra.

59. Desharnais v. C.P.R. [1942] 4 D.L.R. 605 (Sask. C.A.): Alberta residents working in Saskatchewan were injured. They brought actions in Saskatchewan against their employer. Alberta Compensation Board made an order in their absence that they were workmen under the Alberta Act and entitled to compensation, fixing the amount of entitlement for each. The C.P.R. then applied in Saskatchewan court to have writs and statements of claim set aside on the grounds the plaintiffs were entitled to compensation under the Alberta scheme and that their actions were barred under Alberta's Workmen's Compensation Act, S.A. 1938, s. 23. Motion was denied. Saskatchewan Court of Appeal said although there was no evidence where in fact the contracts of employment had been made, it would have made no difference if the contracts had been made in Alberta and had even incorporated the provisions of the Alberta Act. The provincial legislatures cannot legislate in derogation of civil rights outside the province. To the extent s. 23 purported to deprive employee residents of Alberta injured in Saskatchewan of a right of action against their employer that was given by the Saskatchewan Workmen's Compensation Act, R.S.S. 1940, c. 302, it was ultra vires.

See also Grimm v. Co-Operative Fire \& Casualty Co. (1981) 129 D.L.R. (3d) 304 (N.S.S.C.): an action was brought by the Quebec Compensation Board under its statutory rights of subrogation against Nova Scotia defendants. Morrison J. held that a workers' compensation plan was not an indemnity scheme and therefore no rights of subrogation arose upon payment of compensation and that in any event the statutory rights of subrogation applied only within Quebec. Desharnais and other cases referred to, including Grey v. Kerslake (1957) 11 D.L.R. (2d) 225, where the Supreme Court of Canada refused to give extra-territorial effect to the Ontario Insurance Act. 
compensation, will not be prejudiced by the mere hypothetical possibility he may be "entitled to receive benefits or compensation under a workers' compensation law or plan." 60

These limitations may have application to offshore suits brought outside of Newfoundland or Canada in the conflict of laws situations that will arise. Attempting to pull together the various ramifications of these propositions for our scenarios is beyond the scope of this paper.

The only case this writer discovered which at all considered the question of the applicability of a provincial compensation scheme vis $\dot{a}$ vis the Merchant Seamen Compensation Act is that of Pare v. Rail \& Water Terminal (Quebec) Inc ${ }^{61}$

In Paré, a shipwreck near the entrance to Ungava Bay lead to the death of the ship's chief engineer. His parents brought suit against various defendants including the owner and charterer, the latter being the deceased's employer. Unfortunately, this case sets out no guidelines for deciding which legislation should apply in a given situation. Addy J. stated that the cause of action was clearly based on maritime law since the allegation was that the death of the seaman was caused by the ship being a "leaky bucket"; i.e., unseaworthy. He then went on to say that either the Workmen's Compensation Act of Quebec or the Merchant Seamen Compensation Act applied, but not both. Because both acts prohibited suits against the immediate employer, Addy J., inter alia, dismissed the action against the charterer. However, he expressly refrained from deciding which of the compensation schemes applied to the situation. He said it was not necessary to decide "since the Federal Court in any case has no jurisdiction";62 that is, since either the Merchant Seamen Compensation Board or the Quebec Commission had exclusive jurisdiction to hear any claim against the employer.

This is an uninspiring result. But given the case law on the question of "exclusive jurisdiction" in Canada, it was probably the only result that could be reached. In the Mack Trucks ${ }^{63}$ case, the Supreme Court of Canada agreed that a provincial compensation board had exclusive jurisdiction to determine such matters as whether an action was barred by the compensation statute. If we can speculate on the combined result of Paré and Mack

60. Chu v. Madill (Lloyd's of London) [1971-75]I.L.R. 1-631 (Ont. C.A.): Plaintiff taxi driver had collision while on job and applied for disability benefits under standard auto policy. Underwriters denied claim on basis of exclusion clause in policy which said "insurer shall not be liable ... for bodily injury to or death of any person ... who is entitled to receive the benefits of any workmen's compensation law or plan." Ontario Court of Appeal, per Arnup J., reviewed the Ontario Workmen's Compensation Act, R.S.O. 1970, c. 505, and said that wherever the term "entitled to receive" was used in the Act, the reference was to cases where the workman had elected to claim compensation, where the Board had decided the claim was well founded, and the Board had made an award.

61. [1978] 1 F.C. 23.

62. Id., 28.

63. Supra $\mathrm{n}$. 33. In Nova Scotia, the Board has exclusive jurisdiction to determine all questions of fact which include "whether or not any person is a workman, a sub. contractor, or an employer within the meaning" of Part I. In effect, the Nova Scotia act attempts to finesse the question of "exclusive jurisdiction" of the Board by treating this as a question of fact only, supra n. 21, s. 139. Appeal courts seldom disturb findings of fact by lower tribunals. The question here of course is whether what is a question of fact can be determined by legislative fiat. The Act also says the Board's decision on a question of fact is final and conclusive. 
Trucks, perhaps the conclusion we can reach is this: any question as to the exclusive jurisdiction of a compensation board should first be determined by the board or boards in question, and only on appeal from such a decision should a higher court consider the matter. ${ }^{64}$

Leaving the problem of a board's "exclusive jurisdiction" aside, even if the rig worker was on a Canadian registered rig, or one chartered by demise to a Canadian resident or someone having his principal place of business in Canada, before we can say the Merchant Seamen Compensation Act applies to him, several other conditions must be met, as we have already seen. These include:

(a) no entitlement to compensation under the Government Employee Compensation Act or under any provincial workmen's compensation legislation; ${ }^{65}$

(b) the rig can be said to be a ship; ${ }^{66}$ and

(c) the worker must be a seaman. ${ }^{67}$

Unless the rig is a ship, it would seem pointless to argue a rig worker is a "seaman". Whether a rig is a ship has been dealt with extensively elsewhere ${ }^{68}$ but it will suffice to say that at the present time the status of a rig as a ship in Canada is uncertain.

While a rig may be registered as a ship, in the one Canadian case directly on point, Dome Petroleum Limited v. N. Bunker Hunt $t^{69}$, the Federal Court Trial Division, per Dube J., decided a rig was not a ship since any navigation engaged in was only incidental to its main purpose of drilling. That decision was never appealed, the parties having settled out of court after the decision was handed down..$^{70}$ In another recent case, The Queen v. Saint John Shipbuilding and Drydock Co. Ltd. and Logistec Corporation $^{71}$, the Federal Court of Appeal held a floating crane was a ship. Application for leave to appeal this result was dismissed by the Supreme Court of Canada. ${ }^{72}$ While there are differences between a floating crane and an oil rig, one cannot help thinking what would have

64. Another way of dealing with the Pare type of case is to borrow the "twilight zone" concept from U.S. jurisprudence and say both provincial and federal compensation schemes can apply. The implication of this is that this type of worker would have no "exclusive remedy" and therefore his action against his employer might not be statute barred. See discussion of this concept in Appendix I, n. 4.

65. Supra n. 11 and n. 3, s. 4(a).

66. Supra n. 3, s. 2.

67. Id, s. 2.

68. Spicer, "Some Admiralty Law Issues in Offshore Oil \& Gas Development" (1982) 20 Alta L Rev. 153. Also see Summerskill, Oil Rigs: Law and Insurance (1979) at 12-85 for a detailed analysis of rig as ship, and application of maritime law concepts and cases thereto.

69. [1978] 1 F.C. 11.

70. See Herman, "The Need for a Canadian Submerged Lands Act: Some Further Thoughts on Canada's Offshore Mineral Rights Problems" (1980) 58 Can. Bar. Rev. 518 at 522-523.

71. (1982) 126 D.L.R.(3d) 353 (F.C.A.), per Urie J.

72. See Canada Weekly Law Sheet, April 23, 1982, issue 8217. 
happened if the rig case had been appealed, ${ }^{73}$ for could it not equally be said of a floating crane that any navigation it was engaged in was only incidental to its main purpose?

Unless the rig is a ship, should the owner, charterer, or other person be subjected to all those liabilities peculiar to ships, such as in rem actions, ${ }^{74}$ salvage claims ${ }^{75}$ and wreck removal responsibilities ${ }^{76}$ ? By the same token, should the rig owner, master and crew, or other person, in theory, have the benefit of limitations on liability under shipping regulations? ${ }^{77}$

But if we assume a rig is a ship, we have both common law and statutory guides as to who is a seaman.

The common law guides or tests are set out in various ship cases. There are general tests such as whether the worker was a seaman by vocation and whether his work was connected with this vocation.$^{78}$ There are tests focusing on whether the worker's employment was of a casual or temporary nature only. ${ }^{79}$ There are tests focusing on whether the work was done in relation to a working or navigating ship as opposed to one tied up to a dock for long periods, out of action..$^{80}$ There is a more specific test as to

73. In a recent U.S. case, a semi-submersible drill rig was held to be a vessel or a ship for purposes of limitation of liability. The Court set out three tests: the craft must be built with the intention that it be used in navigation as a means of transportation, it must not be permanently attached to the shore or seabed, and it must be subject to the perils of the sea. See In The Matter Of the Complaint of Sedco, Inc, as Owner of the Mobil Drilling Unit Sedco 135, etc., Civil Action No. H-79-1880, (U.S.D.C., S.D.Tex., Houston Div.), per Order of Judge O'Conor, March 30, 1982 (U.S. case law deciding rigs are ships for other purposes also reviewed).

The author thanks Gerald Godsoe for reminding him that in the recent S.I.U. offshore labour relations case, the decision of Thurlow C.J. contains strong dicta to the effect that drill rigs are ships (see n. 13, supra, at 13-14) - no case law is cited, but such dicta may be a signal as to the leanings of the Federal Court of Appeal on this issue.

74. As a non-ship, a rig should not be subject to an in rem action unless it is "cargo" on a ship or part of its apparel or equipment. See McGuffie, Admiralty Practice, British Shipping Laws, Vol. 1, par. 69, and ss. 22 and 43 of Federal Court Act, R.S.C. 1970 (2nd Supp.), c-10, which covers the court's jurisdiction over in rem actions, and n. 75, infra, for an example where a rig could be considered "cargo". If a rig cannot be arrested, it can still be the subject of a Mareva injunction. See Third Chandress Shipping Corp v. Unimarine S.A. [1979] 2 All E.R. 972 (C.A.).

75. Only recognized objects of salvage can be salvaged. These include a ship, her apparel and cargo and the wreck of these, and freight. If a floating rig is not a ship, it's unlikely to be an object of salvage. But what if a rig is being carried by something else which may be a ship? Recently in Halifax'Harbour, a jack-up rig carried on a submersible deck barge broke loose from its moorings, creating a hazard to navigation and to one of the bridges spanning the harbour. Barge and rig eventually were secured by a number of federal government naval auxiliary vessels. Both barge and rig were arrested and not released until a bank signed a letter of guarantee as security for the claim. Currently two actions in progress: The Queen v. The Barge Seacamel/393-11 F.C. No. T-2150-82; Paul M. Brick v. The Barge Seacamel 393-11 F.C. No. T-2188-82.

76. Canada Shipping Act, R.S.C. 1970, c. S-9, ss. 486-513. Baker and Underdown, "Legal and Tax Problems and Abandonment" (1981) Int. Bus. Law. 463, discuss implications of Art. 5.5 of Geneva Convention on the Continental Shelf 1958, which says: "Any installations which are abandoned or disused must be entirely removed". This is an obligation of the coastal state, which may require indemnification from the owner and operator or alternatively may order them to carry out the removal. But is a rig an installation? See discussion of this term, infra, re U.N. Convention on the Law of the Sea.

77. Canada Shipping Act, id, ss. 647 to 655.

78. Macbeth v. Chislett [1910] A.C. 220, appd. in Jorgensen v. "The Chasina" [1926] 1 D.L.R. 1193 (B.C. Adm.).

79. Cleugh v. Canadian Pacific R. Co. (1918) 40 D.L.R. 512 (B.C.C.A.).

80. Walter W. Brown v. The Ship "Flora"(1898) 6 Ex. C.R. 133. 
whether the person had a contract of employment with the ship or its managers. ${ }^{81}$

The statutory guides are set out in the general definitions of "seaman" in legislation such as the Canada Shipping Act ${ }^{82}$ and Merchant Seamen Compensation Act. ${ }^{83}$ If our courts decide or if Parliament legislates that a rig is a ship, prima facie, all those employed on the rig are seamen for purposes of the legislated definitions referred to.

In summary, the following general guidelines may be useful in determining which compensation scheme applies to a given "offshore" scenario. First, prima facie, the provincial compensation scheme applies where there is some connection between a worker's offshore work and his employer's base of operations within the province and where there are other connections to the province, such as the province being the worker's place of domicile or residence, and the contract of employment being concluded within the province. Second, the Merchant Seamen Compensation Act applies only to "seamen" and therefore only to employees on a "ship", but does not apply to all "seamen" and the eligible seaman must not be entitled to compensation under some other federal or provincial compensation scheme. Thus in most cases, prima facie, this Act will not apply to an offshore worker. Third, where there is a serious question as to "exclusive jurisdiction" of one or more compensation boards, the question should be decided in the first instance by the board or boards in question, with further clarification coming from an appeal to a higher court.

With respect to the last point made, it does not appear that the suggested process is what automatically occurs. ${ }^{84}$

\section{A. Legislative Competence and Jurisdiction in Respect of the Offshore}

What is the legislative competence of the provinces and of Canada in relation to the offshore? The legislative competence of Newfoundland has been severely questioned by Herman. ${ }^{85}$ The issue he addresses may be of limited relevance if we are concerned only with a worker's civil right to claim compensation under the Newfoundland Act. Arguably, to paraphrase Viscount Haldane in Workmen's Compensation Board v. Canadian Pacific Railway Co. ${ }^{86}$ the Act serves only to secure a statutory contractual right of a workman within the province, and does not purport to regulate offshore activity per se.

The issue of legislative competence is important however in assessing the efficacy of the purported "exclusive jurisdiction" of compensation boards as set out in their respective statutes. The Newfoundland Act, for example, says the Compensation Board has exclusive jurisdiction to examine into, hear, and determine all matters and questions arising under Part $1 .^{87}$ We have seen judicial recognition in both provincial courts ${ }^{88}$ and the

81. Joseph A. McElhanney and others v. The Ship "Flora"(1897) 6 Ex. C. R. 129, 131.

82. Supra n. 76, s. 2.

83. Supra n. 3, s. 2.

84. See Carino Company Limited and Geophysical Service Inc. v. All Persons or Parties Claiming. . . In Connection With The Sinking of the Canadian Ship "Arctic Explorer" F.C. No. T-4480-81. This case is discussed again infra, re remedies of employers.

85. Supran. 70.

86. Supra n. 57, case discussed thereat.

87. Supran. 33.

88. Id. 
Federal Court ${ }^{89}$ of this sort of legislative reservation of exclusive jurisdiction. If, as Herman argues, only the federal government has legislative competence in relation to the offshore areas, ${ }^{90}$ how can we also allow that the Newfoundland Compensation Board has "exclusive" jurisdiction to determine all issues arising out of an offshore casualty resulting in injury or death? Surely such exclusive jurisdiction cannot extend beyond Newfoundland's own territorial sovereignty?

\section{U.N. Convention on Law of the Sea.}

Nation states have adopted and refined, over the centuries, many rules and principles in their efforts to keep their interactions with other nation states harmonious and predictable. Collectively, these make up that legal regime known as international law. A coastal state's ability to interfere with or control offshore activities, including the right to interfere with a rig (whatever status it may have as a ship) is affected by that branch of international law known as the law of the sea.

On April 30, 1982, the United Nations voted to adopt a comprehensive Convention on the Law of the Sea. The Convention passed with 130 votes for, 17 abstentions, and 4 votes against. Canada voted for the Convention, as did France, Japan, and various developed and third world countries. The abstaining nations included the United Kingdom, West Germany, and other developed nations from the European Economic Community and from the Soviet bloc. The signing ceremony took place on December 10, 1982. The Convention was signed by 119 countries, including Canada and France. Japan did not sign, but will apparently do so later. Included in the 24 countries that did not sign, but which had participated in previous Law of the Sea conferences, were the United States, West Germany, Belgium, Italy and the United Kingdom. The Convention will come into force one year after 60 nations have ratified it.

The Convention the U.N. voted on was basically the same as the official draft convention produced by the Third U.N. Conference on the Law of the Sea at its meeting on August 24,1981..$^{91}$ (The changes appear mainly to concern the arrangement for mining the resources on the floor of the high seas; i.e., deep sea bed mining, and consequently do not affect oil rig drilling on the continental shelf.)

89. See discussion of Pare at 29.30, supra notes 60 and 61 .

90. Herman, supra $\mathrm{n}$. 70. He argues, inter alia, that before the Geneva Convention of $\mathbf{1 9 5 8}$ on the Territorial Sea and Contiguous Zone, in international law there was no gener. ally recognized right in coastal states to claim "sovereign" territorial ownership beyond the low water mark. This has obvious implications for Newfoundland which entered Confederation in 1949. Prior to that 1958 Convention, the concept of a territorial sea connoted in international law a coastal zone over which the coastal state had some legislative competence, but which never became part of its territory. Brownlie, in Principles of Public International Law (1973, 2nd ed.) at 184-186, traces the history of the concept. It begins with coastal sovereigns exerting control over offshore ships by the range of their coastal cannons. This elaborates into a belt of hypothetical cannon shots along the seaboard forming a zone of uniform breadth, eventually becoming standardized at a breadth of one marine league or three nautical miles. Over this zone, the coastal state exerted a limited functional and legislative jurisdiction that slowly began to harden into claims of sovereignty. The development culminates with Article 1 of the Convention of 1958 which says coastal states have rights amounting to sovereignty over the territorial sea. (This notion has been incorporated into the UN Convention on the Law of the Sea, which is discussed infra.).

91. U.N. Doc. A/Conf. 62/L. 78, 28 August 1981. Under art. 311, this new Convention is meant to replace the Geneva Conventions on the Law of the Sea 1958. 
There is good reason to expect the proposed treaty will be viable. It provides a code of many accepted principles of the international law of the sea. This can only increase certainty and predictability in the application of international law principles by nations around the world. It provides and in some cases extends the rights coastal states have been advocating for themselves, albeit with due regard for the traditional rights of innocent passage through the territorial seas and freedom of the high seas that have been jealously guarded by seafaring nations.

Some brief comments on what the Convention says as to the rights of coastal states in regard to the Territorial Sea and beyond follow.

(a) Territorial Sea. Every coastal state has the right to establish the breadth of its territorial sea up to a distance of 12 nautical miles from the low water mark or other baseline. ${ }^{92}$ The coastal state has sovereignty over this zone, extending to the air space above and to the ocean bed below. ${ }^{93}$ But this sovereignty is to be exercised subject to the Convention and to other compatible rules of international law. ${ }^{94}$

Foreign ships enjoy rights of innocent passage through the territorial sea. ${ }^{95}$ "Passage" and "innocent passage" are defined, ${ }^{96}$ including specific instances of what is not innocent passage. The coastal state may pass laws and regulations regulating innocent passage, ${ }^{97}$ but such laws and regulations shall not apply to the design, construction, manning or equipment of "foreign ships" unless they conform to generally accepted international rules or standards. ${ }^{98}$ Presumably, an oil rig is not such a foreign ship. If it is not a ship, prima facie, a foreign oil rig would not have rights of innocent passage either.

The criminal jurisdiction of the coastal state is not to be exercised on board a foreign ship during its passage, except in certain limited circumstances, the basic one being where the crime threatens the peace of the country or the good order of the territorial sea. ${ }^{99}$

The coastal state's civil jurisdiction is not to be exercised on a foreign ship. ${ }^{100}$ But an exception is made for executing against or arresting the ship for liabilities assumed or incurred "by the ship itself in the course or for the purpose of its voyage through the waters of the coastal State."101

Traditionally, in international law, a ship has been treated with deference as an extension of the territory of its flag state under the theory that

92. Supra n. 91, art. 3.

93. Id, art. $2,2$.

94. Id, art. 2,3 .

95. Id, art. 17.

96. Id, art. 18 and art. 19 respectively.

97. Id, art 21,1 .

98. Id. art. 21,2 .

99. Id., art. 27,1. Criminal jurisdiction is to be exercised on board a foreign ship only in four cases: if consequences of the crime extend to the coastal state, if the crime is of a kind to disturb the peace of the country or the good order of the territorial sea, if master or diplomatic agent or consular officer of the flag state requests assistance of the local authorities, or if necessary to suppress illicit traffic in narcotic drugs or psychotropic substances. These limitations are not in S. 433(1) of the Criminal Code, R.S.C. 1970, c. C-34, as am., which gives authority to the courts to try anyone committing an offence on the territorial sea or internal waters of Canada. Also see ss. 681.682 of the Canada Shipping Act, supra n. 76.

100. Id., art. 28,1 .

101. Id., art. 28,2 . 
it was like a "floating island". ${ }^{102}$ If a rig is not a ship, however, it is possible a coastal state may show less deference and exercise the jurisdiction it is permitted to exercise over all ships in its internal waters; that is, inside the low water mark, the coastal state may exercise its criminal and civil jurisdiction over a ship for any infractions of its criminal and civil laws committed while therein. ${ }^{103}$

(b) Exclusive economic zone. An exclusive economic zone is established beyond and adjacent to the territorial sea, up to a distance of 200 nautical miles from the low water mark or other baseline.$^{104}$ Over this zone, the coastal state has "sovereign rights" over the exploration and exploitation of natural resources, living and non-living, and "jurisdiction" in relation, inter alia, to establishing and using artificial islands, installations and structures. ${ }^{105}$ In particular, the "coastal state shall have exclusive jurisdiction over such artificial islands, installations and structures, including jurisdiction with regard to customs, fiscal, health, safety and immigration laws and regulations." ${ }^{106}$ An oil rig could certainly be a structure, which is a fairly general term. Similarly, it could be an installation.

Beyond that particular jurisdiction, the coastal state has only a limited jurisdiction over ships which are to enjoy the traditional freedom of the high seas, subject to the usual limitations that allow interference by the coastal state for suspected universal crimes such as piracy and slave trading, for being suspected of having no nationality or having a doubtful nationality, and subject to the coastal state's traditional right of "hot pursuit." 107 The right of hot pursuit is the right of a coastal state to go after a foreign vessel believed to have infringed its laws and regulations while in its territorial sea. The pursuit must be commenced while that foreign vessel is still within the outer limit of the 12 mile territorial sea, the pursuit must be continuous and uninterrupted, and the right of hot pursuit ceases when the pursued vessel enters the territorial sea of its own country or that of a third state. ${ }^{108}$ It is of course rather ludicrous to imagine a coastal state in hot pursuit of a slow moving oil rig.

While in place and drilling, an oil rig is presumably an installation or structure and therefore is subject to the coastal state's customs, fiscal, health, safety and immigration laws and regulations. If so, when the rig is not in place but navigating to another location, does it become a ship and receive the benefit of the freedom of the high seas? Or alternatively, does it always remain something less than a ship, and if so, does the coastal state have any civil or criminal jurisdiction over it in addition to the customs, fiscal, health, safety and immigration laws and regulations specifically

102. See P.M. North, Cheshire and North's Private International Law, (10th ed. 1979) 290 note 5. Article 5, paragraph 1 of the Convention on the High Seas of 1958 says "Each State shall fix the conditions for the grant of its nationality to ships, for the registration of ships in its territory, and for the right to fly its flag. Ships have the nationality of the State whose flag they are entitled to fly. There must exist a genuine link between the State and the ship; in particular, the State must effectively exercise its jurisdiction and control in administrative, technical and social matters over ships flying its flag" (emphasis supplied). Also see supra n. 91, arts. 91-94.

103. Supra n. 91, art. 27,2 and art. 28,3.

104. Id, art. 57.

105. Id., art. 56.

106. Id., art. 60,2 .

107. Id., art. 58 and arts. 87 to 115 .

108. See art. 23 of the Convention on the High Seas of 1958. 
referred to? ${ }^{109}$ In the absence of anything explicit in the Convention, one has to fall back on other principles and sources of international law, ${ }^{110}$ assuming there are any that effectively apply to the situation. For example, the Comite Maritime International adopted a draft International Convention on Off-Shore Mobile Craft at Rio de Janeiro in September, 1977. The Convention has not been accepted generally by nation states, but it is instructive to look at what the Convention attempted to do. Basically it equated ships and offshore craft for specific purposes. It defines offshore craft as ${ }^{11}$

any marine structure ... not permanently affixed into the sea-bed which (a) is capable of moving or being moved whilst floating in or on water, whether or not attached to the sea-bed during operations, and (b) is used or intended for use in the exploration, exploitation, processing, transport or storage of the mineral resources of the sea-bed or its subsoil or in ancillary activities.

Such craft, which obviously include a semi-submersible oil rig, are treated generally as ships for purposes such as collisions, salvage, arrest, limitation of liability, liens and mortgages, and liability for pollution. However, the C.M.I. report to I.M.C.O. on that Draft Convention recognizes certain problems in attempting to equate offshore craft and ships: ${ }^{12}$

(1) The definition of what a ship is differs widely from one country to another;

(2) Many states find it desirable to treat ships and craft differently (we see this in relation to the safety regulations that apply to offshore drilling units in Canadian law, ${ }^{113}$ but not to ships);

(3) Offshore craft are not built like ships, which makes it difficult to measure them for purposes of limitation tonnage; and

(4) Registration of drilling units is often for purposes other than for title or rights; e.g., for complying with inspection and certification requirements of the coastal state having jurisdiction over the drilling site.

(c) Continental shelf. The coastal state may establish a continental shelf zone which may extend up to 350 nautical miles from the baseline. ${ }^{114}$ The coastal state has sovereign or exclusive rights over exploration and exploitation of non-living natural resources found in its continental shelf. ${ }^{15} \mathrm{In}$ this zone, the coastal state also has exclusive jurisdiction over artificial islands, installations and structures, including jurisdiction with regard to

109. Supra n. 106.

110. Supra n. 91 , art. 58,2 .

111. Art. 1. See New Directions in Maritime Law 1978, Dalhousie University Faculty of Law, in which the draft Convention is reproduced in Appendix V.

112. See "Introductory Report to the Legal Committee of IMCO from the Comite Maritime International" which is reproduced as part of Appendix V in New Directions in Maritime Law 1978, id. I.M.C.O. is short for Inter-Governmental Maritime Consultative Organization, a specialized agency of the U.N. It is basically an advisory body to its member states on technical, environmental and safety aspects of shipping.

113. Canada Oil and Gas Drilling Regulations, SOR/79-82, as am., SOR/80-641.

114. Supra n. 91, art. 76. It is interesting that given the alternative baselines that can be used, in some places the Canadian continental shelf could extend out as far as $\mathbf{4 7 0}$ nautical miles, if the measurement is made in relation to paragraph 5 of article 76 which says the actual limits of the continental shelf shall not exceed 100 nautical miles from the 2,500 metre isobath, which is a line connecting the depth of 2,500 metres. Personal communication from Norman Letalik of Dalhousie Ocean Studies Programme.

115. Id., art. 77. 
customs, fiscal, health, safety and immigration laws and regulations thereto. ${ }^{116}$

As for criminal and civil jurisdiction of the coastal state beyond the exclusive economic zone to the outer edge of the continental shelf, it will be similar to whatever jurisdiction it had in the exclusive economic zone. That is, foreign ships will continue to enjoy the freedom of the high seas, subject to the same constraints mentioned above with respect to the exclusive economic zone. ${ }^{117}$ The same questions remain as to the status of the rig in such a legal regime; that is, beyond any customs, fiscal, health, safety and immigration laws and regulations it may be subject to.

Briefly, the draft Convention does little or nothing to clarify the status of a rig in the legal regimes a coastal state may erect for "ships" in the territorial sea, exclusive economic zone, and continental shelf. What is clear, though, is that the coastal state has exclusive jurisdiction over regulating artificial islands, installations and structures in terms of customs, fiscal, health, safety and immigration matters. If we assume a rig is an installation or a structure, we can also assume that in the newly emerging law of the sea the coastal state has exclusive legislative competence for regulating and setting such standards for offshore oil rigs.

Even if it is assumed the coastal state has exclusive legislative competence for regulating and setting standards for offshore oil rigs in terms of customs, fiscal, health, safety and immigration matters, it remains arguable that workers' compensation legislation does not fit under any of those heads of jurisdiction. We have seen that in our own constitutional law, such legislation is a matter of civil rights. In the Nova Scotia offshore, the writer understands Workers' Compensation used to exempt employers with Norwegian employees because they had coverage under Norwegian compensation schemes. Although the present policy is to require coverage under the Nova Scotia Workers' Compensation Act of all employers, regardless of the circumstances of their employees, one can appreciate that in some cases the result is the worker will have access to more than one compensation scheme. Thus he has no "exclusive remedy."

Does it not follow that to impose the Nova Scotia compensation scheme on such a worker as his "exclusive" remedy is an interference with his civil rights? If one allows that it is an interference with civil rights in his case, one must also allow in regard to a worker who has no other coverage, that we are still dealing with a matter of civil rights and not merely with the regulation of fiscal, health or safety matters.

Where the oil rig is a foreign flag vessel and there are few connections with Newfoundland or any other part of Canada, it becomes highly questionable whether the coastal state has any exclusive jurisdiction over such matters as the type of compensation a worker is eligible for and whether or not he has any rights of action aside from such compensation.

Perhaps the way out of this impasse is for the coastal state to require as part of its licensing process in regard to offshore drilling that the rig's employers and employees submit to the jurisdiction of its domestic workers' compensation legislation. That solution may get around any objections based on international law to the imposition of the coastal state's workers' compensation laws.

116. Id., art. 80 and art. 60 .

117. Supran. 107. 
(d) Federal-Provincial Agreements. The ongoing dispute between Canada and Newfoundland as to who has jurisdiction over the offshore leaves us with a degree of uncertainty as to the legal regimes that must be observed by offshore operators and workers. The dispute in effect is whether it is Canada or the province which is the "coastal state" which is recognized in international law as having jurisdiction to legislate in respect of coastal offshore areas. ${ }^{118}$ The problems inherent in such a dispute have been sidestepped in Nova Scotia by the recent Canada-Nova Scotia Agreement on Offshore Oil and Gas Resource Management and Revenue Sharing. ${ }^{119}$ Under that agreement, federal legislation will basically apply to the Nova Scotia offshore. However, the agreement also allows Parliament to apply to the offshore such provincial laws as may be specified. It is to be expected that the province's Workers' Compensation Act ${ }^{120}$ will continue to apply to the offshore, just as it is at the present time.

Should Newfoundland enter into a similar agreement, we would expect that part of the agreement would allow for the application of that province's workers' compensation legislation to the offshore.

\section{TORT ACTIONS FOR WRONGFUL DEATH}

The typical causes of action and the relevance of statutory duties and standards of care to the tort actions that can be expected to result from offshore casualties will be discussed. It will be assumed that the dependants have rights of action that are not statute barred against the employers.

Generally speaking, "negligence" principles governing wrongful death appear fairly uniform throughout the common law world. But there are significant differences nevertheless, including statutory variations which affect the course of litigation in different jurisdictions in important ways. The "other" jurisdiction which looms large for purposes of the present scenario is, of course, the United States. Canadians perceive, rightly or wrongly, that they will get larger awards in the United States and that American lawyers are much more willing than their Canadian counterparts to undertake wrongful death or injury cases on strict contingency terms.

This section will review briefly the basics of negligence law, and then will consider products liability, occupiers' liability, and the applicable duties and standards of care.

\section{A. Negligence and Wrongful Death}

The basic cause of action in wrongful death cases is negligence. This will require proof of the defendant's duty of care to the injured or deceased worker, proof of the relevant standard of care, proof such standard was breached by the defendant, and proof such breach was an effective or proximate cause of the injury or death. A discussion of these principles can be found in practically any standard textbook on torts. ${ }^{21}$

118. Both Newfoundland and Nova Scotia have legislation purporting to regulate offshore drilling activities: e.g., the Petroleum and Natural Gas Act, R.S.N. 1970, c. 294, and the Petroleum Resources Act, S.N.S. 1980, c. 12. Discussion of such legislation is beyond the scope of this paper. The Nova Scotia Act has not been proclaimed.

119. Concluded March 2, 1982.

120. Supra n. 21.

121. See Fleming, supra n. 5. 
Where death results from an injury, at common law there was no cause of action for the loss of continued support this entailed to the survivors. ${ }^{122}$ This unsatisfactory situation changed with the enactment of statutes modelled on Lord Campbell's Act. ${ }^{123}$ These wrongful death statutes give the executor or administrator the right to sue on behalf of the deceased's dependants for loss of "those material benefits which depended on the continuance of the life of their breadwinner." 124

The equivalent Nova Scotia statute is the Fatal Injuries Act, ${ }^{125}$ which is similar to corresponding statutes in the other common law provinces. The limitation period for starting an action is usually measured from the date of death, rather than the date of the injury, and in Nova Scotia is one year. ${ }^{126}$ This means the limitation periods for personal injuries set out in the general statutes of limitations do not apply when the injuries incurred cause death.

In the United States, there are several different federal statutes that may have application in maritime tort situations involving the wrongful death of a worker. There are also state wrongful death statutes which can apply in certain situations. In addition to statutory remedies, the United States Supreme Court created a remedy under general maritime law for wrongful death cases that has complicated the picture somewhat. In depth analyses of these areas and of the complexities of federal and state courts' jurisdictions are beyond the scope of this paper but Appendix I has some brief notes on these matters. ${ }^{127}$

\section{B. Products liability}

In products liability cases there is a duty of care, in Anglo-Canadian law, on the designer, manufacturer, assembler, supplier, repairer, or installer of a product not to negligently design, produce, assemble, supply, repair, or install a product, so that if such negligence causes injury or death to the ultimate foreseeable user of the product, that person will be liable for damages, even though there may be no privity of contract between the parties. ${ }^{128}$

In American law, there is apparently no necessity of proving negligence or fault in products liability cases. All that has to be proved is that a defective product caused the injury or death - the so-called doctrine of "strict liability". ${ }^{29}$

The following quote from Swan is a propos: $:^{130}$

122. Baker v. Bolton (1808) 1 Camp. 493, 170 E.R. 1033, discussed by Fleming, id. at 647.

123. $9 \& 10$ Vic., c. xciii.

124. Fleming, supra n. 5 at 651.

125. R.S.N.S. 1967 , c. 100.

126. Id., s. 9.

127. See Appendix I, n. 9 re a matter of particular relevance to the subject of this paper; i.e, Bill H.R. 4863 which, if passed into law, will make it virtually impossible for a Canadian rig-worker or his dependant to bring suit in the U.S. courts for an offshore injury or death.

128. See Linden, Canadian Tort Law (2nd ed., 1977), chapt. 15.

129. Id, 502.

130. Swan, Ocean Oil and Gas Drilling \& the Law (1979) 275; see 275-295 for a discussion of American and Scandinavian products liability law relevant to offshore. See also Kuffler, "Products Liability Afloat" [1976] 1 L.M.C.L.Q. 33 at 33-45 for a review of such cases heard by U.S. admiralty courts as of about 1975 . 
Many offshore oil platforms are essentially custom-made. This means that the design and engineering work can have a crucially important effect on how well and how safely they perform their intended functions. This in turn suggests that errors or short-sightedness in design can be the cause of property loss to the facility owner and personal injuries and death to employees, business visitors, and even conceivably bystanders ..... Errors in design can bring liability to the designer, both under negligence and under strict liability theories. In fact, as to certain issues the two theories converge. For analysis, it is convenient to separate "design" into its conceptual component and its physical component. In the latter, component errors could consist of miscopying dimensions on blueprints, computational mistakes when specifying materials of adequate strength, mislabeling or mismatching of part numbers, inaccurately recording tolerances or other specifications.

In the offshore scenario we are dealing with, if the casualty was effectively caused by the design or manufacture of the rig's structure, or by the design or manufacture of a component part, there may be a products liability action available to a worker's dependant. If the intended defendant is not an employer for the purposes of a provincial compensation scheme, the plaintiff's rights of action will be unimpeded by any constraints on litigation contained in such legislation.

\section{Occupier's Liability}

The basic allegation in occupier's liability is that the defendant was an occupier of dangerous premises (i.e., the rig) and therefore had a duty to the deceased (i.e., to the worker as a contractual entrant) to make the premises safe, which duty was breached, and which caused the death or injury. ${ }^{131}$

An occupier is anyone who has control of the dangerous premises. Total or exclusive possession is not essential. Thus, there can be multiple occupiers of the same premises. On an oil rig the different companies involved in its day to day operations are all potentially occupiers for such actions.

The common law occupier's liability action supplements the similar statutory causes of action referred to in Part II of the Workers' Compensation Act, ${ }^{132}$ which was noted previously.

If the negligent act of an employee caused injury or death to someone else, his employer can be held responsible under the doctrine of "vicarious liability" if the negligent employee was acting in the "course of his employment" at the time. ${ }^{133}$

But can an occupier absolve his liability by saying he relied upon an independent contractor who caused the damage? Both statutory and common law trends are to exonerate an occupier where the danger was due to faulty work by an independent contractor reasonably assumed to be competent and where the occupier took whatever reasonable steps he could to supervise the work and see the job was properly done. ${ }^{134}$ In the leading Canadian case of Hillman v. MacIntosh, ${ }^{135}$ a so-called independent contractor was held to be the occupier's employee. The occupier was held liable because the dangerous condition caused by this employee's negligence could have been discovered by reasonable inspection.

131. Di Castri, Occupiers' Liability (1980).

132. See discussion, supra.

133. Christie, supra n. 9 at 15-17.

134. Di Castri, supra n. 131, chapt. 8.

135. 8 D.L.R.(2d) 513, affd. 17 D.L.R.(2d) 705 (S.C.C.). 
The critical question is what the occupier knew or should have known. This may turn on the occupier's expertise and resources, but is also determined by the "class" of entrant, whether trespasser, licensee, invitee, or contractual. The extent of duty increases as we move from trespasser to each of the other aforementioned classes. The contractual entrant is owed the highest duty, and this class includes such people as oil rig workers for the purposes of our scenario. The contractual entrant "is entitled to enter without risk of danger so far as reasonable care could make the premises safe; or . . . there is an implied warranty that the place is reasonably fit for the purposes for which it was intended." ${ }^{136}$

At one time, the premises giving rise to occupier's liability were limited to land or structures on land. Today the category of dangerous premises includes moveable structures such as aircraft, ships and streetcars "where the defective condition of the moveable structure is the cause of the injury."137

An oil rig that is defective could be such dangerous premises. There is an obvious duty on offshore operators to maintain the rig in good operating condition, including a duty to undertake preventive maintenance through such measures as appropriate inspections. Swan states: ${ }^{: 18}$

\footnotetext{
On the whole, it appears that offshore operators are cognizant of the importance of inspections and preventative maintenance although specific procedures and instrumentation are evolving only as more experience is gained. If errors of recording or interpreting data or failures to act upon evidence of a potential problem or failures to even undertake inspection are proven, there will be liability under familiar neglience (sic) standards once a causal linkage to the harm suffered has been shown. A much more difficult problem concerns a failure of the inspection procedure to detect an incipient problem. Here one would expect defendants to have success relying on the "state of the art" defence....
}

\section{Duties and Standards of Care}

At the beginning of this paper a brief reference is made to the "Kielland" disaster. While the initial cause of the disaster appears to have been construction defects in the rig, personnel on board had little or no experience or training in offshore safety procedures. Although the "Kielland" had 200 per cent lifeboat capacity, only two of seven lifeboats were successfully launched..$^{139}$ It is stated that "panic ... was the greatest enemy aboard the rig that night." 140

The duties and standards of care of offshore operators do not end with their obvious responsibilities to ensure as much as reasonably possible the soundness of the rig's structure and mechanics. They are also responsible for adequate operating procedures, including procedures and training in safety.

What should the potential defendant look to with respect to applicable

136. Supran. 131 at 17.

137. Supran. 131 at 12-13.

138. Supra n. 130 at 327.

139. McIntosh, "How dangerous is offshore drilling" (August 1981) 16 Ocean Industry 17 at 22-24 and 138, 141.

140. Id. at 138.

141. Linden, supra n. 128 at 216. In the leading case of Horsley v. MacLaren (1972) 22 D.L.R.(3d) 545 (S.C.C.), the court applied a provision of the Canada Shipping Act to cast a duty on the owner and master of a boat to do what he could to rescue a guest who had fallen overboard. The court did not feel the statutory provision by itself created the tort duty, but stated "new tort obligations may be established by analogy to these provisions." See Linden at 293. 
duties and standards of care? Statutory regulations for oil rigs provide explicit statutory duties and standards of care for regulatory purposes. Beyond regulatory purposes, however, they are relevant evidence as to what such duties and standards should be at common law. ${ }^{141}$ As Linden says, "When statutes deal with dangerous activities, the courts tend to accord their violation more weight than they do to the infraction of other legislation." 142

In some cases the courts have said that a breach of a statutory duty and statutory standard of care was sufficient to prove the negligence. ${ }^{143} \mathrm{In}$ other cases the courts have said that the statutory duties and standards of care are not codes governing civil liability, but represent evidence of what reasonable duties and standards may be. ${ }^{14}$

There have been many cases where courts have refused to rely on statutes to create new civil duties. The court may refuse because it disagrees with the policy inherent in the statute, or because the statutes lack uniformity from one jurisdiction to another, or because it feels the statutory sanction (often a fine) is sufficient. Similarly, the courts have not always adopted statutory standards. ${ }^{145}$

While courts may apply statutory duties and standards of care to impose civil liability, they will take care to ensure the appropriate duties and standards are applied. In this regard, consider Northern Helicopters Ltd. v. Vancouver Soaring Association. ${ }^{146}$ There was a collision between a helicopter and a glider. Both pilots were killed. Both had violated air regulations passed under the Aeronautics Act. ${ }^{147} \mathrm{Mr}$. Justice Berger noted that a court applying such regulations must do so in a sensible way that takes into account the special characteristics of the aircraft involved. $\mathrm{He}$ said that to apply law developed in automobile cases or collisions arising at sea would risk being arbitrary and insensitive to the peculiarities of flight. By implication, we should not arbitrarily apply statutory rules and regulations that have been developed for "ships" to tort actions involving "oil rigs."

For our offshore scenario, the relevant duties and standards are perhaps indicated for tort purposes by such legislation as the following:

1. Canada Oil and Gas Drilling Regulations; ${ }^{148}$

2. Certain regulations under the Canada Shipping Act, ${ }^{149}$ such as the Life Saving Equipment Regulations, ${ }^{150}$ Non-Canadian Ships Safety Orders, ${ }^{151}$ Safe Manning Regulations, ${ }^{152}$ and the Safe Working Practices Regulations. ${ }^{153}$

Are these appropriate for oil rigs?

142. Id. at 216.

143. Id. at 216, re Ostash v. Sonnenberg (1968) 67 D.L.R.(2d) 311.

144. Id. at 218.

145. Id. at 300-304.

146. (1972) 31 D.L.R. (3d) 321 (B.C.S.C.).

147. R.S.C. 1952 , c. 2.

148. SOR/79-82 and SOR/80.641.

149. Supra n. 76.

150. CRC 1978, c. 1436, as am..

151. Id., c. 1452.

152. CRC 1978, c. 1466.

153. Id., c. 1467. 
The Canada Oil and Gas Drilling Regulations cover, inter alia, safety standards required of offshore rigs operating in waters subject to Canadian jurisdiction. These regulations require anyone wanting to drill a well to obtain a "Drilling Program Approval". The application for such approval must include details as to various safety characteristics of the rig. The regulations go on to say, for example, that every operator is to repair or replace defective equipment and alter any operational procedure that is unsafe, inadequate or deficient. There are specific requirements in regard to support craft, standby craft, meteorological forecasting facilities, safety devices and guards, medical and rescue facilities, emergency electrical power, firefighting systems, communications facilities, alarm systems, operating manuals, contingency plans for foreseeable emergencies, safety and training of personnel, life jackets, record keeping of information relevant to safety, and reporting requirements.

The adequacy of such standards for tort purposes is to be questioned in each case, as is the extent of operator's compliance with a given standard. ${ }^{154}$

Presumably, when the operator submits his application, the details given of his proposed operation will take into account the various regulatory standards previously mentioned. But it does not follow that once approval is granted, for tort purposes, the operator has complied with all necessary duties and standards. Nor does it follow that merely passing periodic inspections by regulatory authorities will insulate an operator or other employer from tort liability. We have already discussed how courts use statutory standards in torts cases. We saw there that courts will not necessarily adopt statutory standards for tort duties and standards of care. Statutory duties and standards should be regarded as only possible guides to the tort duties and standards that will pertain. Fleming discusses judicial reluctance to adopt regulations as the source of duties in the following way: $:^{155}$

A potent factor which has militated against certain regulations being construed as a source of duties . . . is the feeling that the categorical legislative prescription would introduce too inflexible a yardstick for measuring civil liability.

One of the main problems with such regulations is that they are often worded so vaguely or loosely that there are no objective criteria given for deciding what is adequate, reasonable and appropriate in a given circumstance. For example, in the Canada Oil and Gas Drilling Regulations, regulation 21 says:

Every operator shall take all reasonable precautions for the protection of personnel and equipment from naturally occurring and man-made hazards in the area described in the Drilling Program Approval issued to that operator.

What does "all reasonable precautions" include? Similarly consider regulation 147:

154. The author was informed by an official in the Nova Scotia Department of Mines and Energy that COGLA issued new "orders" to offshore operators after the Ocean Ranger disaster, with respect to life-saving equipment, including the matter of survival suits. A representative of a manufacturer of survival suits told the author that since the Ocean Ranger disaster their suits have been selling like "hot cakes". There were apparently no survival suits on the Ocean Ranger. Newfoundland Regulation 149/82, s. 204 , says that survival suits are to be provided in the accommodation areas and at survival craft embarkation stations for at least 200 per cent of persons normally on board a drilling unit. This regulation came into force on June 16, 1982.

155. Supran. 5 at 127. 
Every operator shall ensure that

(a) any operation necessary for the safety of personnel employed at a drill site or on a support craft has priority, at all times, over any other operation on that drill site or craft;

(b) trained personnel are ready and able to operate any item of equipment; and

(c) safe working methods are followed in all operations during any drilling program.

What "necessary" operations? What "trained personnel"? Trained how? What "safe working methods"? An attempt is made in other regulations to indicate the sorts of things to which regulation 147 is referring, but these are woefully inadequate.

Regulations under the Canada Shipping Act, such as those referred to above suffer from the same limitations. In addition, however, shipping regulations have the added problem of being designed for "ships" in the traditional sense of the word, rather than for oil rigs. Thus, there is a question as to how appropriate it is to control the marine activities of oil rigs by such means. ${ }^{156}$

\section{CURES AND PREVENTION}

In this section, the non-contractual "cures" or remedies available to an offshore employer after an offshore casualty has occurred will be looked at first, followed by a discussion of the contractual devices he can use to protect himself before such a disaster strikes.

\section{A. Non-contractual Remedies}

After an offshore casualty of the "Ocean Ranger" type, the employer has several options. Not all of these require the sanction of the court.

For example, the employer could "assist" dependants in applying for workers' compensation benefits. Is the giving of such "assistance" ethical? If workers' compensation is the sole and exclusive remedy of the dependants in any event, there is no obvious ethical problem. However, if the dependants have the option of electing compensation or litigating the claim through the courts, given that, prima facie, obtaining compensation results in the Compensation Board being subrogated to "all rights" of the deceased worker and his dependants, the giving of such "assistance" may be treading the fine line between what is ethical and unethical behaviour.

156. With respect to the Ocean Ranger, the Canadian Coast Guard (CCG) apparently accepted a U.S. certificate of "seaworthiness" rather than making its own inspection. That information was given to the author by an official of the federal Department of Energy, Mines and Resources. He was informed by another knowledgeable source that prior to the Ocean Ranger incident CCG treated self-propelled rigs as ships while they were moving, but that when they were in place and drilling, jurisdiction and control over them were assumed by Energy, Mines and Resources, which treated them as if they were structures on land. However, it appears a comprehensive agreement will soon be reached between CCG and COGLA, giving CCG a wider range of duties and obligations with respect to rig operations. The author perused a preliminary draft of the proposed agreement recently. It provides, inter alia, that at the request of COGLA, CCG will inspect installations, structures, vessels and support craft used in offshore energy exploration and development, where such are "not otherwise subject to survey or inspection under the Canada Shipping Act." In carrying out such inspections, CCG will, unless otherwise agreed, inspect as if such objects were subject to inspection under the Shipping Act or Arctic Waters Pollution Act and their regulations. The inspections will cover not only structural integrity, but operations, seaworthiness, navigability, stability, safety including safety equipment, practices and procedures. The draft agreement will probably go through further revisions and amendments before a final agreement is reached. The source referred to above agreed we could probably expect "new" regulations governing various aspects of rig operations in the near future, but he could not say whether those would be under the Shipping Act or under legislation sponsored by Energy, Mines and Resources. 
More straight forward and academic are the various court applications an employer can make if he is embroiled in or threatened by litigation from the deceased's dependants, particularly if litigation is started in American courts. A shopping list of the sorts of applications that can be made is contained in the pleadings filed in the wake of the "Arctic Explorer" sinking that was mentioned previously.

In that matter, a Statement of Claim was filed in the Federal Court asking for various remedies. The "Defendants" were named generally as those persons having or being entitled to any claim as a result of the sinking.

The "Arctic Explorer" was being used for marine oceanographic geophysical survey work off the East Coast of Canada. The ship was operated for this purpose in Canadian waters only. On July 3, 1981, it foundered and sank approximately five miles off the northern tip of Newfoundland. Five of the marine crew and eight of the scientific personnel were lost.

Both the registered owner of the vessel and the time charterer were scheduled and assessed employers under the Newfoundland Workers' Compensation scheme. Both were American companies. The specific remedies asked for in the Statement of Claim included the following: ${ }^{157}$

1. A declaration that all persons on board the ship when it sank were covered by and subject to the provisions of the Workers' Compensation Act of Newfoundland or the Merchant Seamen Compensation Act or both and therefore no action lay by, or in respect of any such person in respect of the sinking;

2. A declaration that the Federal Court is the "forum conveniens";

3. An injunction preventing the defendants from commencing, continuing or maintaining any action, proceeding or claim in any jurisdiction without the leave of the Federal Court, or alternatively, an injunction preventing them from doing so except in a court of competent jurisdiction in Canada;

4. A declaration stating which court or courts or tribunals have jurisdiction in respect of the claims arising out of the sinking;

5. General damages, special damages, punitive damages, and indemnity from anyone commencing, maintaining or prosecuting an action, proceeding or claim in any jurisdiction for recovery of damages or other relief from the plaintiffs;

6. Alternatively, a declaration that the plaintiffs are entitled to limitation of liability under the Canada Shipping Act;

7. Directions from the court for ascertaining who may have claims arising from the sinking; and

8. Such further and other relief as the court considers just and proper.

The Statement of Claim of course includes an application for a declaration that the plaintiffs are not liable to any defendant for any losses, damages, costs or expenses arising out of the sinking. That of course is a general denial of liability even before any action has begun by a survivor or dependant.

Parallel proceedings appear to have been taken in the "Arctic Explorer" matter in the United States to deal with the actions commenced 
in Texas in respect of claims arising out of the sinking. In the Federal Court file on the matter in the Halifax Federal Court Registry, there is a newspaper notice, which appears to be a copy of a notice filed by the charterer, Geophysical Service Inc., and by its parent company, Texas Instruments, Inc., in the United States District Court for the Southern District of Texas, Houston Division. This document gives notice to all concerned that upon the filing of a limitation complaint in that Court, said Court "restrained all suits or actions ... pending in all courts of the United States", that the charterer and its parent company have asked the American court to dismiss or stay all actions against them, so that they are to be heard only in the Federal Court of Canada, and that if the American court refuses to do this, they have asked the American court to apply the limitation of liability provisions of the Canada Shipping Act.

The proceedings referred to in the "Arctic Explorer" matter, taken in both the United States and Canada, are reminiscent of Canadian Pacific Railways' tactics in Desharnais. ${ }^{158}$

If workers, seamen and their dependants have rights of action in the United States, can Canadian provincial or federal compensation laws effectively deprive them of such rights?

The "Arctic Explorer" matter is in some respects similar to Paré ${ }^{159}$ In both cases we have a situation which is similar to that which pertained in the American case of Hahn v. Ross Island Sand \& Gravel Co. ${ }^{160}$ In Hahn, the United States Supreme Court had to deal with a situation in which a prima facie determination could not be made as to whether a worker fell under a federal or a state compensation scheme. The Court decided that in such a "twilight zone" either statute could apply. This meant further that since the worker has no "exclusive" remedy, his employer's argument that the worker's sole remedy was under the federal compensation statute failed. Accordingly, the worker's action against the employer was sustained. Whether our own federal court would adopt this "twilight zone" concept is difficult to say. However, an American court, faced with the conflict of laws situation that must develop when a Canadian survivor or dependant brings suit in the United States, may well apply the twilight zone concept in regard to the survivors' or dependants' rights under our federal and provincial compensation schemes. If that happens, we should not expect a Paré type of decision.

In the "Arctic Explorer" matter, there is at the present time a judicial inquiry being held before Mr. Justice Mahoney of the Newfoundland Court of Appeal. Litigation in this matter is not expected to move ahead until at least this inquiry is over. This particular case could be quite instructive if it goes ahead to complete resolution by trial and appeal. If, however, it gets settled out of court, it will only have raised intriguing possibilities.

\section{B. Contractual Devices}

Summerskill says there is no "standard" drilling contract that is regularly used. He says while "virtually every significant operating oil company or offshore drilling contractor has what it considers to be its own form of contract" these "however, frequently serve as nothing more than

158. See n. 58, supra.

159. Supra n. 60.

160. See Appendix I, infra, n. 4. 
the basis for a request for a bid or an offer of services. Once interest is generated actual contractual negotiations may occupy several weeks and the final contract may bear little resemblance to the original form". ${ }^{161}$ This is an important point. It may mean the final contract bears little resemblance to a contract of adhesion and that the parties were more or less on equal bargaining terms. If so, the doctrines of fundamental breach and contra proferentem may have little application to exclusion clauses and clauses which to an outsider appear to strongly favour one party at the expense of the other. In any event, the application of the notion of fundamental breach in Canada is uncertain as is evident in several recent Canadian decisions which attempt to apply the House of Lords decision in Photo Production Ltd. v. Securicor Transport Ltd. ${ }^{162}$ What application contra proferentem has will depend on who drafted the particular clause in question. This rule basically is that where a clause can be given different interpretations, each favouring a different party, the meaning adopted by the court will be that which is against the interest of the party who drafted the clause. Thus we can expect if the clause was jointly drafted, the rule cannot come into play. ${ }^{163}$

Although no standard drilling contract may be executed in the field, there is a model precedent we can look at as a source of the types of clauses that might be used in the final agreement. This is the "International Daywork Drilling Contract - Offshore" which Summerskill refers to as the I.A.D.C. contract. ${ }^{164}$

There are various indemnity clauses that can be used. For example, one clause may say:

Operator agrees to protect, defend, indemnify and save Contractor harmless from and against all claims, demands and causes of action of every kind and character, without limit and without regard to the cause or causes thereof or the negligence of any party, arising in connection herewith in favour of Operator's employees, Operator's contractors or their employees (other than those identified in Clause 1003 above) or Operator's invitees, on account of bodily injury, death or damage to their property.

\section{Summerskill comments on this clause as follows: ${ }^{165}$}

Some words of warning are necessary; the language used may not be sufficiently wide or specific to meet the requirements which the courts, especially in the United States, apply when considering whether a party should be indemnified in respect of its own negligence.

The point is well taken. The drafter must return to the basics of drafting contracts. He should draft clauses in clear, comprehensive, and specific language to avoid creating ambiguities. The above clause would be

161. Summerskill, supra n. 68 at 249 .

162. [1980] 1 All E.R. 556, revg. - [1978] 3 All E.R. 146. The ostensible result in this case is that there is no substantive rule of law where a fundamental breach automatically nullifies an exclusion clause, the court must look to the wording of the clause and the whole contract. In effect if a clause is drafted sufficiently clearly and precisely, etc. to exclude liability for a fundamental breach, that clause will prevail. See discussion by Palmer and Evans of this case in 58 Can. Bar Rev. 773. The Canadian cases applying Photo Production Ltd. include Beaufort Realties (1964) Inc. v. Chomedey Aluminum Co. Ltd. (1980) 13 B.L.R. 119 (S.C.C.) and Canadian-Dominion Leasing Corp. Ltd. v. George A. Welch \& Co. (1981) 125 D.L.R. (3d) 723 (Ont.C.A.). Reader should consider whether Photo Production Ltd. represents a general rule of contract law, or whether it is restricted to specific situations; e.g., where the parties are on equal bargaining terms and the transaction is a commercial one.

163. See G. Fridman, The Law of Contract (1976) 255, notes 1 and 2.

164. The contract is given in full in Appendix B of his book, supra $n .68$.

165. Id. at 263. 
improved in this regard if it said specifically that the agreement to indemnify was to cover even those situations where the contractor's own negligence, including the negligence of its own employees or subcontractors, was the effective and proximate cause of death, injury or other damage. $^{166}$

The I.A.D.C. contract also has a clause which creates a parallel indemnity obligation in favour of the Operator: ${ }^{167}$

1003. CONTRACTOR'S PERSONNEL.

Contractor agrees to protect, defend, indemnify and save Operator harmless from and against all claims, demands, and causes of action of every kind and character, without limit and without regard to the cause or causes thereof or the negligence of any party, arising in connection herewith in favour of Contractor's employees, Contractor's subcontractors or their employees, or Contractor's invitees, on account of bodily injury, death or damage to their property.

One problem that arises with such interlocking indemnity agreements is that their existence is a material fact which can affect the acquisition and enforcement of insurance coverage. Summerskill mentions, for example, that if P. \& I. Club insurance is obtained, which normally provides coverage for liabilities under indemnities and other contracts, the Club is not under any liability to a member unless the indemnity agreement had been approved by it. ${ }^{168}$ There are other problems that arise because of interlocking indemnity agreements. The following statements by HopeRoss are relevant in this regard: ${ }^{169}$

In many offshore accidents, the responsible party is not easily identified. Therefore, it is desirable to set forth in the contract the areas in which each party shall be responsible. Keeping that in mind, it is clear that many of the indemnity clauses now in use in offshore operating agreements are not very useful.

Indemnity clauses in offshore contracts are often entirely reciprocal. That is, the operator agrees to save harmless the contractor against all claims brought against the contractor and vice versa. The results are less than satisfactory. Such clauses tend to spawn litigation in order to determine responsibility. As mentioned earlier, underwriters refuse to insure pollution risks partly because of the problems of sorting out the indemnity agreements among the innumerable joint owners, contractors, and subcontractors involved in a drilling operation.

...

Some contracts stipulate that each party to the operation shall be responsible for his own employees and equipment notwithstanding that harm may come from another's negligence, the theory being that each can insure against his own risks and should not be concerned with the risks of others. The problem with this scheme is that it is essential to have the same agreement with each and every contractor on the project....

The scheme which no doubt has the most appeal to the readers of this paper is that in which the oil company operator, because of its superior bargaining power, insists upon indemnity from all the contractors and subcontractors while giving nothing in return. Such an operator can be oblivious to the problem created thereby for the apportionment of responsibility among those contractors and subcontractors. It is to be hoped that the draughtsmen of indemnity clauses will appreciate the injustice of such documentation before the courts strike it down as unconscionable.

Choice of law clauses should have application in both the drilling contract and the individual employment contract.

Employment contracts are often unwritten, supplemented however by statutory requirements such as those contained in workers' compensation legislation, labour standards legislation, and a variety of other statutes

166. Another 'basic' of drafting is to explicitly make every important term a condition so that it cannot be construed as a mere warranty.

167. Summerskill, supra n. 161 at 268.

168. Id at 215.

169. W. J. Hope-Ross, "Insurance and Indemnity Problems in Offshore Drilling Operations" in Offshore Oil and Gas Law Cases and Materials, Canadian Institute of Resources Law 1980, 369 at 373. 
that affect employers and employees. ${ }^{170}$ Written employment contracts have the advantage that specific clauses not found in such statutory requirements can be explicitly incorporated. It may be particularly advantageous to put a choice of law clause in an employment contract.

The choice of law clause could provide that in the event of an offshore casualty, any outstanding claims would be decided under the laws of, for example, Newfoundland. The clause could include specific legislation as the choice of law, such as the Workers' Compensation Act. It could refer specifically to those sections of the Act that limit and affect rights of action. It could say the parties submit themselves to a particular jurisdiction or court.

The choice of law clause could be supplemented by an arbitration clause. This could provide, in the event of a dispute or a claim arising out of an offshore injury or death, for a resolution of the dispute by mandatory arbitration. The place of arbitration would be provided, usually a place that is convenient for all parties.

Choice of law clauses will not necessarily be followed. In $R$. v. Thomas Equipment Ltd., ${ }^{171}$ the Supreme Court of Canada considered whether a choice of law clause in a contract could prevent the application of an Alberta regulatory statute. The statute provided that on termination of a dealership agreement for farm implements, the manufacturer was obliged to repurchase the unused implements. If he did not, he was subject to a fine. The dealership agreement in question said the rights and duties of the parties were to be determined according to New Brunswick law. The manufacturer was based in New Brunswick. The dealer was in Alberta. For the majority, Martland J. said that when the manufacturer sold the farm implements to the dealer for resale in Alberta, it rendered itself subject to the provisions of the Alberta regulatory statute. He also said the statutory obligation stood independent of the contract. The choice of law clause was therefore irrelevant in this context in that it could govern the parties' respective rights and obligations only apart from the statute.

Apart from the effect of overriding statutes, a choice of law clause will often be given effect nonetheless. A recent case illustrating this is $G \& E$ Auto Brokers Ltd. v. Toyota Canada Inc. ${ }^{172}$ In this case, the defendant applied for a stay of proceedings commenced in a British Columbia court on the grounds that the contract it had with the plaintiff said: ${ }^{173}$

This agreement shall be interpreted according to the laws of the Province of Ontario; should any dispute of any kind arise in connection with this agreement, including but not restricting the generality of the foregoing, any question in respect of the interpretation, validity, termination or non-termination of this agreement or any renewal thereof, the parties agree to submit to the jurisdiction of the Courts of the Province of Ontario exclusively.

Mr. Justice MacFarlane reviewed the applicable case law and held that the proceedings should be stayed. There are two parts to his rationale. First, he says, as per Lord Denning in Re The Fehrman, ${ }^{174}$ that a court is not bound by a choice of law clause and has the discretionary power to give effect to it or to ignore it. Second, where the words "exclusive" were used, a

170. See Christie, supra n. 9 at 1 - 3.

171. (1979) 96 D.L.R.(3d) 1. See discussion of this case by H.P. Glenn in 59 Can. Bar Rev. 840.

172. (1981) 25 B.C.L.R. 145 (S.C.).

173. Id. at 146.

174. [1958] 1 All E.R. 333 (C.A.) at 335. 
heavier onus was on the plaintiff to show why the court should not exercise its discretion and grant the stay of proceedings. In the circumstances, he said the onus had not been satisfied and accordingly the defendant's application to have the plaintiff's action stayed was granted. Mr. Justice MacFarlane did not agree with the approach of the Saskatchewan Court of Appeal in E. K. Motors Ltd. v. Volkswagen Can. Ltd. ${ }^{175}$ or with the approach of Furlong C.J. of the Newfoundland Supreme Court in Westcott v. Alsco Products of Can. tdd $^{176}$ In both cases, the courts were of the view that the mere use of the word "exclusive" before the word "jurisdiction" was determinative of the issue.

Whether the use of the word "exclusive" determines the issue or whether it only places a heavier onus of proof on the plaintiff that starts an action outside of the exclusive jurisdiction, it would seem prudent to say in the choice of law clause that the parties agree to submit to a specific court or tribunal exclusively or words to that effect. It might say, for example, that the parties agree to submit to the exclusive jurisdiction of the Newfoundland Workers' Compensation Board in respect of any issue referred to in the governing Act, including whether an action in respect of a worker's injury or death is barred by that statute. ${ }^{177}$

The arbitration clause, if one is used, should not be inconsistent with the choice of law clause. If it says arbitration is to be the exclusive remedy in the event of a dispute, the choice of law clause should not say the parties agree to submit to the exclusive jurisdiction of a "court" of Province X.

Arbitration has been found useful in commercial dealings, particularly as a more convenient and often less expensive alternative to resolving disputes through litigation. In some cases, this advantage proves to be illusory due to careless drafting of the contract.

The I.A.D.C. contract has an arbitration clause in which either party to the contract, prior to its having filed a complaint or petition in any court of law, may elect to have the claim or dispute referred to arbitration. This clause is as follows: ${ }^{178}$

1402. Arbitration

As between the parties, any claims, disputes or controversies arising under or in connection with this Contract which cannot be adjusted by mutual agreement will be decided by the Courts of ............. to whose jurisdiction the parties hereto agree, whatever their domicile may be; provided that either party prior to its having filed a complaint or petition in any court of law, may elect to have any such claim, dispute or controversy referred to arbitration in .............. in accordance with the provisions of the ................. Arbitration Act or any statutory modifications or reenactment thereof for the time being in force.

A final comment is that courts will often refuse to give effect to an arbitration clause if it is only going to result in increased costs and inconvenience and therefore be against the interests of the parties. ${ }^{179}$

The I.A.D.C. contract also has various insurance clauses. These could be improved in various particulars. For example, one clause says that there is to be insurance to cover "personnel" in accordance with the law of the jurisdiction where the work is being performed or in accordance with

175. [1973] 1 W.W.R. 466 (Sask. C.A.).

176. (1960) 26 D.L.R.(2d) 281 at 284.

177. The I.A.D.C. contract's choice of law clause does not specify "exclusive jurisdiction".

178. Summerskill, supra n. 68 at 449.

179. See for example D. Sassoon, 5 British Shipping Laws (2nd ed., 1975) $\$ 298$. 
applicable laws of other countries. That proviso is vague in that it does not tell us what kind of insurance is to be placed on those persons. Also, there is a clause which says that the contractor's underwriters waive their rights of recourse against the operator and that the operator in turn will cause its insurer to waive subrogation against the contractor. However, nothing in that clause explicitly says what the operator's insurance is supposed to cover. While the answer may be implied by an analysis of the various obligations of the operator, it should not be necessary to go through that mental exercise.

The basic criticism to be made about clauses in the I.A.D.C. contract is that the language is not often precise enough, specific enough or comprehensive enough to tie down with certainty what is meant.

\section{CONCLUSION AND SUMMARY}

It is clear that workers' compensation issues are important to the outcome of litigation arising from an offshore casualty. There are complex issues underlying the application of workers' compensation legislation to the offshore. The questions of legislative competence and jurisdiction of the coastal state in relation to the offshore were canvassed from the constitutional and international law of the sea perspectives. A proposal was made as to how such issues might be sidestepped by requiring offshore employers and employees to submit to the jurisdiction of a given compensation scheme as part of the licensing process of rig operations. There was a brief discussion as to how, at least on the domestic scene, the issues of legislative competence and jurisdiction in relation to the offshore may be finessed by federal-provincial agreements relating to offshore development. In this regard, reference was made to the recent Canada-Nova Scotia Agreement.

The uncertainty in Canadian law as to whether a rig is a ship has implications regarding the application of the federal Merchant Seamen Compensation Act and regarding the applicability of a given legal regime to the regulation of activities and movements of an oil rig in the offshore.

Tort actions were briefly discussed. Special emphasis was given to products liability and occupier's liability. The relations between statutory requirements and tort duties and standards of care were examined. It was seen that courts do not necessarily base tort duties and standards of care on statutes meant for regulatory purposes.

The paper concluded with a discussion of examples of contractual and non-contractual stratagems that could be adopted by an employer in 
attempting to insulate his bank account from the claims that would arise out of an offshore casualty. ${ }^{180}$

\section{APPENDIX}

The following notes on the U.S. law of wrongful death and injury are based on Norris, The Law of Maritime Personal Injuries (3rd ed.), except where otherwise indicated.

1. The Jones Act 46 USC $\oint 688$, covers "seamen" who die as a result of injuries suffered in the course of employment. It supercedes any otherwise applicable state death statute. The personal representative of the seaman may maintain an action on behalf of specified survivors for two types of damages: (i) re seaman's personal loss and suffering before he died (contra: Engerrand \& Brann, "Troubled waters for seamen's wrongful death actions" 12 J.M.L.C. 327 at 337-338, n. 70, who say the Jones Act has been consistently interpreted as limiting recovery to pecuniary losses only); and (ii) re resulting pecuniary losses to those survivors.

2. The Death on the High Seas Act 46 USC $\oint 761-768$, gives a remedy for death caused by a wrongful act occurring beyond one marine league (or three nautical miles) from shore. Remedy is not restricted to seamen. But the personal representative of the seaman can bring suit under this statute as well as the Jones Act. The action is for the benefit of designated surviving beneficiaries. Damages claimable are only for pecuniary loss sustained by those survivors. No claim for conscious suffering of the deceased prior to his death can be made.

3. The Outer Continental Shelf Lands Act 43 USC $\oint 1331$ et seq., inter alia, provides that "artificial island drilling rigs" located beyond the three mile limit are not within federal maritime jurisdiction, which means the Death on the High Seas Act will not apply to wrongful deaths occurring as a result of injuries sustained on such artificial islands. The appropriate remedy is to be found in other provisions of the Outer Continental Shelf Lands Act as supplemented by the law of the adjacent State.

4. The Longshoremen's and Harbor Workers' Compensation Act 33 USC $\$ 901$ et seq., was the end result of legislative response to a case in which it was held a State worker's compensation scheme did not apply to a maritime shore worker, in this case a longshoreman, who was killed while

180. A non-contractual strategem not mentioned that may be useful in reducing rig owner's exposure to liability before disaster strikes, is to have ownership of different rigs in different limited companies. Assuming their 'corporate veils' are not pulled aside, this should have two desired effects: (i) in those jurisdictions that treat rigs as ships for in rem actions and which allow "sister ships arrests" this would prevent such sister ship arrest of an "innocent" rig for damage occasioned by or on a different rig; and (ii) it may keep an "innocent" rig out of the clutches of a Mareva injunction taken in respect of a claim arising out of an incident involving a different rig.

In some jurisdictions, an in rem action is not allowed for a maritime wrongful death or injury case, so that the first of the above considerations may not be relevant. In the U.S., this is the situation, as understood by the author.

In Canada, sister ship arrests are not allowed. Further, an in rem action for wrongful death or injury is allowed only if it was "caused by a ship either in collision or otherwise" (Federal Court Act, R.S.C. 1970, c. 10 (2nd Supp.), s. 22 (2)(d), emphasis supplied). The case law suggests it is not enough that the damage was caused on a ship. It is necessary to prove the ship itself was the chief or active cause. Such active cause includes negligent navigation or other negligent management by those in charge of the ship. See cases cited by Hughes, Federal Court of Canada Service, vol. 1, in respect of s. $22(2)(d)$. 
working aboard a ship. This Act both complements and overlaps with State compensation laws. If the injury occurs in an activity pertaining to "local" matters (i.e., not directly concerned with navigation or commerce), the local State law will apply. However, in the "twilight zone" where it is difficult to make this determination prima facie, the court may decide the worker is entitled to compensation under either this act or under the State compensation scheme. Such a result has important implications to a worker's rights of action. The U.S.S.C. in Hahn v. Ross Island Sand \& Gravel Co. (1959) 358 US 272, held since the worker's injury came within the "twilight zone", there was no "exclusive" remedy and he could therefore maintain his suit against the employer (who had maintained the worker's sole remedy was under the Longshoremen's and Harbor Workers' Compensation Act).

Where the employer has secured compensation under the scheme, there is no right of action against him (except if it's a "twilight zone" situation, supra). The injured worker, however, can bring a third party suit against the shipowner under the common law of negligence, unless he was directly employed by shipowner (in which case he is treated as an ordinary longshoreman with his exclusive remedy under the compensation scheme).

This Act does not cover the master or crew of any vessel, who have other remedies as "seamen." It does cover longshoremen and other shore workers. The test as to whether a given worker is a seaman appears to be whether the work is in connection with a vessel on navigable waters and whether it pertains in some way to navigation. Norris says, "In recent years off-shore drilling and construction activities have seemingly given a novel twist to the seaman concept. But basically the principles" are as indicated in the tests referred to (see Norris supra, vol. 1, at 129).

5. State wrongful death statutes. In addition to the above federal statutes, there are State statutes that are based on Lord Campbell's Act (supra $\mathrm{n}$. 123). In most States, the remedy is limited to damages for pecuniary loss to designated beneficiaries. But in some States, the remedies include the right to claim damages in respect of the pain and suffering of the deceased before his death.

6. In Moragne v. States Marine Lines, Inc. (1970) 398 US 375, the U.S.S.C. created an additional remedy for wrongful death under general maritime law. A longshoreman was killed while working onboard a ship in Florida waters. An action was filed in a Federal District Court. This was dismissed on two grounds: (i) maritime law did not allow an action for death based on seaworthiness; and (ii) the Florida wrongful death statute did not encompass seaworthiness as a cause of action. The Court of Appeals for the Fifth Circuit affirmed this trial decision. The U.S.S.C. however granted certiorari, reversing the lower courts, and declaring an action lay under general maritime law for wrongful death due to violation of maritime duties.

Since Moragne, judicial attempts to trace the limits of this new remedy in various situations have come up with varying results. Engerrand \& Brann (supra n. 1 of this Appendix, at 335) state this has only led to "confusion and conflict in interpreting the new remedy."

7. Any discussion of the complicated matters of U.S. Federal Court jurisdiction on its admiralty side as opposed to its civil side, and the relation of these to the jurisdiction of the State courts is beyond the scope of this paper 
and the reader is referred to Norris supra, vol. 1, c. v.

8. For a discussion of the conflict of laws issues that arise when a "foreign" worker brings suit in the U.S. for incidents occurring outside of the U.S. in foreign waters, see Sutterfield, "Foreign offshore worker injuries in foreign waters - why a United States forum?" (July 1981) I.C.J. at 472. Also see Baer, Admiralty Law of the Supreme Court (3rd ed.) c. 5.

9. Finally, note that amendments have been recently proposed to the Jones Act. Bill H.R. 4863 (97th Congress, lst Session) proposes to prohibit actions under the Act or under any other maritime law of the U.S., inter alia for injury or death of a person who was not a citizen or permanent resident alien of the U.S. at the time of the incident, if the incident occurred while that person "was engaged in the exploration, development, or production of offshore mineral or energy resources - including drilling, transporting supplies or personnel, mapping, surveying, diving, pipelaying, maintaining, repairing, or constructing, but not including transporting those resources by vessel" and if the incident occurred "in the territorial waters or waters overlying the continental shelf of a nation other than the United States, its territories, or possessions . . .".

Bill H.R. 4863 goes on to say that notwithstanding the above provisions, "an action may be maintained if the person bringing the action establishes that, at the time of the commencement of the action in the United States, no remedy was available to that person under the laws of the country ... asserting jurisdiction over the area in which the incident occurred; or ... . in which, at the time of the incident, the person for whose injury or death a remedy is sought maintained citizenship or residency."

"In a surprise move that caught even some legislative leaders unaware," the substance of the above provisions "slid through" the Senate and the House of Representatives on December 10, 1982, "as part of a commercial fisheries bill". That Bill will become law when signed by President Reagan. There is to be apparently no retroactive effect of the provisions. See The Globe and Mail, December 14, 1982. 